\title{
Property Rights Protection and Bank Loan Pricing*
}

\author{
Kee-Hong Bae \\ and \\ Vidhan K. Goyal
}

July 2003

\begin{abstract}
We use data from 37 countries to examine how property rights affect loan spreads (over LIBOR or prime) in international bank loans. We find that banks charge higher loan spreads when property rights are weaker. These effects are economically large. If a country improved its property rights protection from the $25^{\text {th }}$ percentile to the $75^{\text {th }}$ percentile, loan spreads would decline by 87 basis points. Governance mechanisms at the firm level affect loan spreads too, but these are second-order effects. An implication of these findings is that improvement in the cost of external financing will be greater with policies that improve property rights protection at the country level than with policies that aim at improving governance mechanisms at the firm level.
\end{abstract}

JEL Classification: D23, G21, G32, K42

Keywords: property rights, creditor rights, law, enforcement, investor protection, loan spreads

* Bae is in the College of Business, Korea University, 1, 5-Ka, Anam-dong Sungbuk-ku, Seoul 136701, Korea; Tel: 82-2-3290-1957; Fax: 82-2-3290-2552; Email: khbae@korea.ac.kr. Goyal is in the Department of Finance, Hong Kong University of Science \& Technology, Clear Water Bay, Kowloon, Hong Kong; Tel.: 852-2358-7678; Fax: 852-2358-1749; E-mail: goyal@ust.hk.

We are grateful to Kalok Chan, Florencio Lopez-de-Silanes, Kwangwoo Park, René Stulz, and K.C. John Wei and to seminar participants at the Korea University, Asian Corporate Governance conference and Korean Finance Association meetings for helpful comments. Goyal acknowledges research support from HKUST research grant \#DAG02/03.BM22. Bae acknowledges research support from the Asian Institute of Corporate Governance at Korea University. 


\section{Introduction}

The property rights protection has important effects on the financial development and growth of a country. Recent research shows that more secure property rights are associated with higher values of stock markets (La Porta et al. (1997)); a higher number of listed firms (La Porta et al. (1997)); higher valuation of listed firms relative to their assets (Classens et al. (2002), La Porta et al. (2002b)); greater use of external finance (LLSV 1997, 1998, 2000); and greater investments from external funds (Rajan and Zingales (1998); Demirgüç-Kunt and Maksimovic (1998)). A common theme in much of this literature is that property rights affect the cost of external financing.

However, much of the evidence in the literature is indirect and most of it is based primarily on debt and equity markets. There is little discussion on how property rights protection affects the default spreads that banks charge when they are lending to firms. ${ }^{1}$ Both the debt and bank loan markets have provided a much greater percentage of external financing than equity markets have. In fact, bank loans have been every bit as important a source of financing as debt markets. ${ }^{2}$ Given the importance of banks in allocating credit to private firms in countries around the world, more attention to understanding what drives the cross-country variation in loan pricing is clearly warranted.

In this paper we ask whether differences in property rights protection matter for loan spreads (over a base lending rate such as LIBOR or prime) in international bank loans after we control for cross-country differences in per capita GNP, banking sector characteristics, lending rates, religion and language.

\footnotetext{
${ }^{1}$ The exceptions are Esty (2002) and Esty and Megginson (2003). Esty (2002) examines how creditor rights protection and law enforcement affect the willingness of foreign banks to lend to domestic projects. Esty and Megginson (2003) examine how creditor rights protection and law enforcement affect the size and concentration of lending syndicates using a sample of internationally syndicated project loans.

${ }^{2}$ See Figure 1, which plots data on the relative importance of different forms of external financing in 49 countries. Debt and equity issuance data are from Thomson Financial and the loan data are from the Loan Pricing Corporation.
} 
Property rights protection affects a lender's ability to recontract. Loan recontracting occurs when material deviations in the borrower's credit quality have occurred subsequent to initial contracting. Banks typically respond to declining credit quality by raising interest rates, demanding more collateral, shortening loan maturity, and further restricting future activities. Recontracting costs are higher when borrowers operate in weak property rights environments. Lenders also bear the risk of contract repudiation. In lending to firms in weak property rights environments, banks will therefore require higher loan spreads to compensate for greater contracting risk.

To examine this prediction, we use data on loan spreads for bank loans in 37 countries. We conduct the analysis in several stages. We first estimate cross-country regressions in which the dependent variable is loan spread. The key variable of interest on the right-hand side is an index of property rights protection. We associate countries with high levels of corruption, higher risk of expropriation, and greater uncertainty about contract enforcement as countries with poor property rights protection. The regressions control for other possible macroeconomic and institutional variables that may also affect loan spreads.

Second, we conduct firm-level analysis in which we control for borrower characteristics and non-price loan terms. The first step in this analysis is to estimate loan spreads as a function of observable borrower risk characteristics at the firm level. We then take the country-level fixed effect estimates from this analysis and test if the property rights index helps explain the cross-country variation in country residuals. This allows us to examine the effect of property rights protection on loan spreads while controlling for variation in observable risk characteristics of borrowers across countries.

Third, we examine if the divergence between ownership rights and control rights affects loan spreads. La Porta et al. (2002b), Claessens et al. (2000), and Faccio et al. (2001) argue that ownership-control disparity affects the controlling shareholder's ability and incentives to 
expropriate minority shareholders and creditors. We examine the extent to which firm-level governance mechanisms affect loan spreads in comparison to the effect that country-level protection of property rights has on loan spreads.

Our results show that in countries with better property rights protection, lenders charge lower spreads on loans. These results are robust. They hold up when we include additional institutional and macroeconomic factors. They also hold up when we control for firm-level heterogeneity in borrower risk characteristics. The benefit of better protection is enormous. By improving property rights protection from the $25^{\text {th }}$ percentile to the $75^{\text {th }}$ percentile, a country can reduce the average spreads on loans to firms in that country by about 87 basis points.

These results provide direct evidence that property rights matter to external financing costs in contrast to the indirect inferences in much of the existing literature. We employ market-determined loan spread data for a large sample of bank loan contracts from countries around the world and consequently do not rely on indirect proxies for cost of capital differences. There is a clear and economically significant decline in the cost of external financing when property rights protection is improved.

Finally, our results show that ownership-control disparity is significantly positively related to loan spreads. These results suggest that banks charge higher loan spreads to compensate for potential expropriation. However, when we compare how loan spreads respond to weak governance at the firm level compared to poor protection of property rights at the country level, the results show that spreads respond more strongly to variation in the property rights index across countries than to variation in ownership-control disparity within a country.

From the perspective of policy makers, it is important to distinguish between improving governance at the firm level and improving country-level institutional factors. Both views have their advocates. One school of thought is that it is important to have rules and regulations protecting 
outside investors to have a better corporate governance system. Consistent with this view, La Porta et al. (2002a) show that laws matter because public enforcement of laws benefits securities markets. An alternative view with a more "law and economics" flavor of financial contracting is that regulation of financial markets is not necessary since financial contracts take place between sophisticated lenders and sophisticated borrowers. As a result, individual firms can and do adapt to even poor legal environments to achieve an efficient corporate governance system. ${ }^{3}$

While both views of the corporate governance have some truth, our evidence is more consistent with the first view. Based on our results, we advocate that policymakers focus on improving country-level institutions since the country-level protection of property rights has a firstorder effect on the cost of financing. Ownership structures and governance mechanisms at the firm level are important but the effect is second order.

The results presented in this paper also have implications on the literature that relates legal and financial systems to a firm's ability to obtain external capital to fund growth. Existing research shows that more secure property rights are associated with higher aggregate investment and faster economic growth. ${ }^{4}$ Our results suggest that provision of more secure property rights is important in the effective functioning of bank loan markets. Secure property rights affect the development of financial intermediaries by improving the terms on which banks lend to borrowers. If firms in countries with secure property rights obtain lower cost bank financing, they are likely to make more investments financed by external financing sources and attain faster growth.

\footnotetext{
${ }^{3}$ Durnev and Kim (2003) argue that their evidence is consistent with this view of corporate governance, showing that firms with profitable investment opportunities, more reliance on external financing, and more concentrated ownership have high-quality governance.

${ }^{4}$ See, for example, Besley (1995), Mauro (1995), Levine (1999), Levine et al. (2000), and Acemoglu et al. (2001). Cross-country research also attempts to establish the causality from financial development to country growth rates. Rajan and Zingales (1998) show that in countries with well-developed financial systems, industries with greater external financing requirements grow relatively faster. Demirgüç-Kunt and Maksimovic (1998, 1999) show that better investor protection makes it more likely that a firm will make greater use of external finance and it will be less constrained in making productive investments.
} 
The paper is organized as follows. Section 2 presents our data and variables. Section 3 gives the summary statistics. Section 4 discusses the main empirical results. Section 5 presents the firmlevel evidence. Section 6 concludes the paper.

\section{Data and variables}

\subsection{Description of the loan database}

The bank loan data are from the Dealscan database, which is assembled and marketed by the Loan Pricing Corporation (LPC). It includes information on loan spreads, loan maturities, and facility sizes for a large sample of loans in countries around the world. While several recent studies examine the U.S. loan transactions using Dealscan, international data are relatively unexplored. Most loans on the database are of two types - (i) lines of credit and (ii) term loans. In a handful of cases, the database lists the loan type as "other" or classifies the loans as acquisition facilities, leases, bankers' acceptances, or letters of credit facilities. These other structures are relatively uncommon (about 5 percent of the database).

The loans are mostly syndicated, i.e. they are underwritten by a consortium of banks, insurance companies and other financial institutions. The median number of lenders is about 8 although this number varies from country to country. The loans are predominantly international loans. In about 90 percent of loans, loan syndicates include lenders that are based in countries other than the country of the borrower.

The loans are reported in US dollars although the loan facilities themselves could be in other currencies. LPC converts the loan amounts into US dollars using the exchange rate on the date the loan is issued. Loans are priced as spreads over the LIBOR or the prime rate. While a majority of loans are priced off the LIBOR rate, many loans use the prime rate as the base lending rate. The data does not allow us to distinguish between loans that are based on LIBOR and those based on prime. However, to control for the effect of cross-country differences in prime rates on loan spreads, 
we control for the lending rates in the regressions. We also examine relative loan spreads defined as loan spread divided by the lending rate as the dependent variable and get qualitatively similar results.

The drawn all-in spread on line-of-credit facilities equals the coupon spread (over LIBOR or prime) plus the annual fee plus the upfront fee/maturity. Term loans are also mostly variable rate contracts and are typically priced as a markup over a market interest rate such as LIBOR or the prime rate. We also obtain loan maturities from the database, which is defined as the difference between the loan origination date and loan maturity date. The loan facility sizes are in US dollars and they are converted into constant 1995 dollars using the CPI indexes for the countries in our sample.

We exclude countries for which LPC reports less than 50 loans and countries for which we have missing macroeconomic data. Thus, we drop Ecuador, Jordan, Sri Lanka, Uruguay, Nigeria, and Zimbabwe because these countries do not have sufficient numbers of loans on the LPC database. We exclude Brazil, Pakistan, Turkey, and Taiwan because information about aggregate lending rates is missing for these countries. We exclude loans offered before 1995 because reporting on loans in the database is less complete before 1995. Thus, our basic data cover loans to firms in 37 countries during the 1995-1999 period.

To examine how borrowers on the LPC database compare to an average firm in the economy, we match (by hand) borrowing firms to the Worldscope database and then examine borrower characteristics. Panel A of Appendix 1 provides descriptive statistics on the borrowers that matched to the Worldscope database. For comparison, Panel B provides descriptive statistics on all firms for the same set of countries in Worldscope. The results show that international banks lend to firms that are among the largest in their respective countries. Both the mean and median assets are almost twice as large as a typical Worldscope firm. Borrowers also are significantly more profitable 
compared to a typical firm with data on Worldscope. Overall, the data suggest that borrowers on the Dealscan database are among the largest and most profitable of firms in the countries. Examining US borrowers on LPC, Strahan (1999) reaches similar conclusions. He shows that borrowers on the LPC database were among the larger and more profitable set of Compustat firms.

\subsection{Measuring property rights protection}

To measure the extent to which a country respects private property rights, we focus on three indexes from La Porta et al. (1998). These three indexes measure corruption, the risk of expropriation of private property, and the risk that contracts may be repudiated. The range for each index is between zero and ten with low values indicating less respect for private property. Following Morck et al. (2000), we combine these three indexes into an additive index of property rights protection. The index measures the extent to which a country's legal systems and institutions enforce all contracts, including government contracts.

To check if differences in bank loan contracts are associated with differences in the specific provisions of each country's commercial laws, we include a creditor rights index in our analyses. The index captures whether laws provide creditors with four specific protections. The first is whether bankruptcy laws prohibit an automatic stay on assets, which would prevent automatic liquidations of insolvent firms by secured creditors. Second, whether secured creditors are permitted to repossess their collateral in bankruptcy or whether some third-party claims takes priority. Third is whether the bankruptcy law prohibits borrowers from unilaterally obtaining court protection from creditor demands. The fourth protection is whether creditors can dismiss managers and replace them with administrators when a firm goes bankrupt.

The regression analyses also include two proxies for culture, religion and language. Stulz and Williamson (2002) argue that culture proxies seem to be more important than legal origin for creditor rights. According to Stulz and Williamson, religions differ in their assessment of investor 
rights. They find that creditor rights are strongest in countries where the main religion is Protestant, regardless of legal origin. They also argue that the Anglo-Saxon type investor protection is common in English-speaking countries because "beliefs are more easily communicated among countries that share the same language”. We obtain each country's primary religion and primary language from Stulz and Williamson, who assembled it from the 2000 CIA World Factbook.

In the baseline regressions, we control for the natural logarithm of GNP per capita and the level of lending rate levels in the country. According to La Porta et al. (1998), creditor rights are stronger in poorer countries than in richer countries, but richer countries have a higher quality of law enforcement. We include the level of lending rates because we want to control for the differences in inflation rates and sovereign risks that might also explain cross-country differences in loan terms. Countries with high inflation rates are subject to greater political risks, as there is a greater likelihood that the government will introduce wage and price controls or tamper with indexes. Higher inflation rates can raise contracting costs for firms and their bank lenders. According to Demirgüç-Kunt and Maksimovic (1999), high and/or variable rates of inflation make it costly for investors and firms to enter into contracts. We also include the direct measure of inflation in our analysis and the results are very similar. The cross-country macroeconomic data are from the World Development Indicators database. In addition to these control variables, we conduct sensitivity tests by including a number of other variables that measure banking sector characteristics and financial intermediary development in the countries in the sample. These variables are described in Section 4.2.

\section{Descriptive statistics}

Table 1 presents the median loan spreads, the median loan maturities, and the loan sizes by country. The table also reports the property rights index for each country, the median lending rate, the per capita GNP, and the institutional indicator variables for each country. The table shows that 
the median of the country median (MOM) loan spread is about 66 basis points. ${ }^{5}$ The median loan spreads range between 20 basis points for loans to firms in Norway and 187.5 basis points for loans to firms in Peru. The median of the country medians loan maturities is five years and the median of the country median loan size is $\$ 200$ million.

Table 2 presents summary data on loan spreads for countries stratified by the property rights index. The summary data reported in the table suggest that loan spreads are indeed higher in countries with poor property rights protection. The table shows that the median loan spreads are about 119 basis points for countries in the bottom third in terms of property rights protection. The MOM loan spreads decline to 76 basis points for countries in the middle third in terms of property rights protection; they decline even further to about 50 basis points for countries in the top third.

Panel B of Table 2 examines loan spreads for lines of credits and term loans separately. Lines of credit are more relationship based and represent commitments to provide loans up to a certain limit. They are mostly used to finance short-term working capital. Banks also make term loans which are used to finance long-term investments. Roughly 56 percent of all loans in our sample are lines of credit. However, the mix varies critically, depending on the extent of property rights protection. In countries where property rights protection is weak, only about 30 percent of loans are lines of credit. In contrast, in countries with strong property rights protection, almost 76 percent of loans are lines of credit. The fact that banks provide more term loans (typically financing long-term investments) to firms in countries with weak protection of property rights suggests that collateral is more valuable to banks when they are lending in countries with less secure property rights. ${ }^{6}$

\footnotetext{
${ }^{5}$ Over three-quarters of the loans in our basic sample are from the United States and the United Kingdom. But since our empirical design focuses on country medians, all countries are weighted equally and countries like the US and the UK, where a large number of loans originate, do not receive any extra weight. Our results are not sensitive to the inclusion or exclusion of US and UK.

${ }^{6}$ An implication of these findings is that in countries with weak property rights, loan contracting will be more "one-shot" or transaction-based rather than relationship-based.
} 
The results show that bank loan spreads are higher for term loans than for lines of credit. Importantly, loan spreads decline as property rights get stronger for both lines of credit and term loans. Figure 2 displays the scatter plot of the median loan spread and the property rights index for 37 countries in our sample. The figure conveys the same basic message - banks charge lower spreads to firms in countries with more secure property rights.

We also examine the non-price terms of loan contracts but do not report this data in a table. The results show that loan sizes become larger as property rights become stronger and loan maturities lengthen as property rights strengthen, regardless of loan type.

Table 3 presents correlation coefficients (and associated p-values) between loan variables and institutional and macroeconomic variables. The property rights index is strongly negatively correlated with loan spreads. Loan spreads are higher in countries with French legal origins and lower in countries with the Scandinavian legal origins. Loan spreads are negatively correlated with the religion dummy, which suggests that loan spreads are smaller in Protestant countries. Loan spreads are also negatively correlated with per capita GNP. In contrast, the correlation between loan spreads and creditor rights and that between spreads and the language dummy show less evidence of statistical significance. Loan sizes are larger in countries with better protection of property rights and higher per capita GNP.

The correlation matrix also reveals interesting relations between institutional and macroeconomic variables. The property rights index and per capita GNP are highly correlated with each other (the correlation coefficient is 0.89 ). Since per capita GNP is a broad indicator of the differences in wealth in each country, the data suggest that richer countries are perhaps better at law enforcement. It is therefore important to control for per capita GNP in loan spread regressions. Property rights are more secure in countries that have a Scandinavian legal tradition and are less secure in countries that use the French civil law tradition. Property rights are stronger in Protestant 
countries and in countries where English is the primary language. The table also shows that lending rates are smaller in countries with better protection of property rights and in countries with higher per capita GNP.

The overall message from Table 3 is consistent with the descriptive statistics reported earlier. The correlations confirm that better property rights protection results in lower spreads.

\section{Regression results}

We begin our empirical analysis by estimating cross-country regressions that examine if differences in loan spreads are accounted for by cross-country differences in property rights protection, while controlling for other factors that may also affect loan terms.

\subsection{Baseline regressions of loan spreads}

Table 4 presents results from regressions on the cross-country data. The dependent variable is the log of the country median loan spreads for bank loans in the sample countries. While we report results for regression specifications in which both the dependent and independent variables are the median values for each country, results are similar when we use country means instead of medians.

We look first at the regression results reported in Column (1) of Table 4. The explanatory variables are the log of the lending rate level in the country and the log of per capita GNP. The coefficient on the lending rate level is positive and that on the log of per capita GNP is negative but both of these coefficients are not significant at conventional levels.

In Column (2) we examine whether the cross-country variation in the creditor rights index explains the variation in loan spreads. The coefficient on the creditor rights index is again not statistically significant. The fact that the creditor rights index does not explain the cross-country variation in loan spreads supports the argument that what matters to bank lenders is not the actual law that provides creditor rights protection, but, instead, how the law is enforced. The enforcement 
is a function of property rights protection. Demirgüç-Kunt and Maksimovic (1999) reach a similar conclusion. These authors argue that a direct statistical relation between the existence of creditor rights and financial contracts is not expected, because the "existence of rights may be necessary but not sufficient to make a financial contract enforceable". ${ }^{7}$

The regression in Column (3) includes the property rights index and the log of lending rates as explanatory variables. The coefficient on the property rights index variable is negative and significant at the 1 percent level. The negative relation between loan spreads and the strength of property rights protection supports the view that property rights protection allows more efficient contracting, and that bank lenders charge lower spreads on loans to borrowers in countries where property rights protection is strong. Together, the log of lending rates and the property rights index explain about 33 percent of the variation in cross-country loan spreads.

When both the property rights index and the creditor rights index variables are included together with the log of per capita GNP and the log of lending rates (in Column (4)), only the property rights index variable is statistically significant.

In Column (5) we include religion and language dummies. As mentioned earlier, many scholars argue that religion and language shape national views regarding property rights (see, for example, Stulz and Williamson (2002)). The results show that the language dummy has a positive and statistically significant coefficient, while the religion dummy has a negative but statistically insignificant coefficient. ${ }^{8}$ The variable that continues to remain significant in all specifications is the property rights index. Together with the lending rate level, the per capita GNP, and the language and religion dummies, the property rights index explains about 44 percent of the variation in loan spreads.

\footnotetext{
${ }^{7}$ In a different context, Esty (2002) finds that creditor rights and property rights affect foreign bank participation in project loan syndicates.

${ }^{8}$ It is possible that religion affects property rights protection and creditor rights and it does not have any explanatory power for spreads beyond these variables.
} 
The main thrust of the results in Table 4 is that loan spreads are smaller in countries with strong property rights protection. These results are not driven by cross-country differences in per capita GNP, the level of interest rates, language or religion. ${ }^{9}$ The overlap between the time period for our sample loans and the Asian currency crisis in the late 1990s causes concerns that these results may reflect the effect of Asian crisis on loan spreads charged by foreign lenders in emerging markets. To address this concern, we re-estimate the regression in Column (5) of Table 4 after excluding Korea, Thailand, Indonesia, Philippines, and Malaysia - countries that were most severely hit by the currency crisis. The results are robust to exclusion of these countries from our sample. The estimated coefficient on the property rights index variable is virtually identical to that in the Column (5) of Table 4. It is also significantly different from zero at the 1 percent level. Additional tests described in Section 4.2 show that the results are also robust to the presence of other explanatory variables.

To get a sense of the economic significance of these results, we examine the predicted decline in loan spreads that will happen if a country at the $25^{\text {th }}$ percentile of the property rights protection index improves its property rights to the level of the country at the $75^{\text {th }}$ percentile. Based on estimates in Column (5) of Table 4 , if a country at the $25^{\text {th }}$ percentile of property rights protection moves to the level of a country at the $75^{\text {th }}$ percentile of property rights protection, with all other variables set at their mean values, the average bank loan spread will decline by 87 basis points. Figure 3 plots the average predicted loan spreads over the entire range of property rights index values when all other variables in the regression in Column (5) of Table 4 are set at their mean values. The figure shows that loan spreads decline substantially over the entire range of property rights index values.

\footnotetext{
${ }^{9}$ The t-statistics reported are corrected for heteroscedasticity. We also used iteratively weighted least squares to estimate both the regression coefficients and standard errors. This technique assigns weights to each observation and observations with high influence receive lower weights (implemented as 'rreg' in STATA). The results from this robust regression technique are qualitatively identical to those reported here.
} 


\subsection{Robustness tests}

This section presents results from sensitivity tests that examine whether there are other explanations for our results. A concern with cross-country analysis is that the regression may omit an important explanatory variable that is really driving the result and that is highly correlated with property rights protection. To rule out several alternative explanations, we include other plausible institutional and macroeconomic factors and examine if including them reduces the significance of the coefficient on the property rights index. In particular, we focus on the legal origin dummies, country risk measures, measures of the structure of the banking sector in a country, and variables that measure the size and activity of debt and equity markets. These sensitivity tests rule out a large number of alternative explanations.

Legal origin dummies: La Porta et al. (1998) show that the legal origin of a country's laws explains the degree of investor protection in that country. English common-law countries offer creditors stronger legal protection against managers. German civil-law countries are protective of secured creditors. Scandinavian civil-law countries are the best in law enforcement. The legal variables are from the La Porta et al. (1998) dataset. The regression results reported in Column (1) of Table 5 include a set of legal tradition dummies. Only the Scandinavian civil-law dummy is significant at the 1 percent level. This dummy has a negative coefficient, which suggests that loan spreads are lower in countries with a Scandinavian civil-law tradition. Since Scandinavian civil-law countries are the best in law enforcement, this result once again confirms that law enforcement is important.

We also examine the effect that including only the French legal origin dummy has on the coefficient of the property rights index in the baseline regression. French civil-law countries are considered weak in investor protection. However, these unreported results show that the conclusions are not sensitive to the set of legal origin dummies included in the regression. The 
French legal origin dummy continues to remain insignificant while the property rights index remains negative and significant at the 1 percent level.

GNP growth volatility: To address concerns that per capita GNP or the lending rate level does not adequately capture country risk, we include GNP growth volatility as an additional measure of country risk. GNP growth volatility is estimated as the standard deviation of the annual growth rate in GNP. As one would predict, the coefficient on the GNP growth rate volatility is positive and significant. These results are presented in Column (2) of Table 5. While banks charge higher spreads when lending to firms operating in more volatile economies, the inclusion of GNP growth volatility does not change our main results on the property rights index.

Share of bank loans in aggregate external financing: To control for the importance of bank loans in supplying external financing in a country, we estimate the share of bank loans in aggregate external financing during the sample period and include it as an additional variable in the baseline specification. One would predict that if banks provide the bulk of the financing with little competition from public debt and equity markets, loan spreads might be higher in that country. The regression results reported in Column (3) of Table 5 show that the bank loan share variable turns out to be unimportant and it does not change the results on the property rights index.

Concentration: An important measure of the banking structure is the degree of concentration in the banking industry. A highly fragmented banking sector may proxy for an underdeveloped financial sector. Concentration also affects the competition that international bank lenders face when lending to firms in a country. This variable is calculated as the fraction of the assets held by the three largest commercial banks in each country, averaged over the $1995-1999$ period. ${ }^{10}$ While the concentration variable itself has no effect on loan spreads, the property rights protection index continues to remain negative and significant at the 1 percent level.

\footnotetext{
${ }^{10}$ The data on concentration variables can be downloaded from the following website: http://www.worldbank.org/research/interest/confs/042003/data.htm.
} 
Restrictions on non-banking activities: Another measure of the bank market structure is the ability of domestic banks in a country to engage in business of underwriting, insurance, and real estate and of the regulatory effectiveness of banks to own shares in non-financial firms. Barth et al. (2003) examine the extent to which each country's regulations restrict a commercial bank's ability to engage in (i) securities underwriting, brokering and dealing, (ii) insurance underwriting and selling, (iii) real estate investment, development and management, and (iv) ownership of nonfinancial firms, and rate the degree of regulatory restrictiveness for each activity on a scale of 1 to 4 . The overall measure of restrictiveness is the sum of these ratings.

Barth et al. argue that fewer regulatory restrictions on the activities of commercial banks produce more efficient and more stable banking systems. They find that countries with regulatory environments that inhibit banks from engaging in the securities business tend to have more fragile financial systems. We therefore include their restrictiveness measure as an additional variable in the baseline regression.

The results show that differences in banking restrictions across countries do not explain the cross-country variation in loan spreads. More importantly, the property rights index remains significant and negative at the 1 percent level with the inclusion of variables that capture the restrictions on banking activities.

Government ownership of banks: We also examine if controlling for government ownership of banks affects the relation between property rights protection and loan spreads. La Porta et al. (2002c) argue that greater government ownership creates distortions and leads to misallocation of resources. On the other hand, proponents of the government ownership of banks maintain that it overcomes informational problems and better directs capital to more productive projects. In either case, the presence of state-owned banks could affect the terms at which international banks lend to firms in an economy. We therefore include a variable that measures the degree of government 
ownership of banks, calculated as the fraction of the banking system's assets that is in banks that are 50 percent or more government owned. The data are taken from Barth et al. (2003). The coefficient on state ownership is negative but it is not significant. Importantly, the coefficient on the property rights index is once again negative and significant at the 1 percent level.

Foreign bank ownership: We include measures of foreign bank ownership since the presence of foreign banks reflects more integration with outside capital markets. We therefore include a variable that measures the fraction of the banking system's assets that are 50 percent or more foreign owned (Barth et al. (2003)). This variable is insignificant but the property rights index variable continues to remain negative and significant at the 1 percent level. We include two other measures of foreign bank penetration from Beck et al. (1999). One is the foreign bank share (number), which equals the number of foreign banks in the total banks, and the other is the foreign bank share (assets), which equals the share of foreign bank assets in the total banking sector assets. Both of these variables are insignificant and inclusion of these variables does not affect the sign and significance of other variables in the regression.

Credit provided by financial intermediaries to the private sector: This variable measures the financial development of an economy. Private credit by banks to the GDP ratio is from a database constructed by Beck et al. (1999). In addition, we examine the liquid liabilities of the financial system relative to GDP and the ratio of commercial bank domestic assets to commercial and central bank domestic assets. These variables also measure the importance of the banking sector, in particular the financial depth and the overall size of the financial sector. In all of these cases, our main results remain robust. These variables do not themselves have statistically significant effects on loan spreads when included in the regression with the property rights index, which is the most significant variable. 
Size and activity of the stock market. We examine the stock market capitalization to GDP ratio, which equals the value of listed shares divided by the GDP and the stock market total value traded to GDP. Our results on the importance of the property rights index are robust to controlling for the importance of the stock market in the economy. In addition, our results are robust to the inclusion of variables that measure the size of the bond markets and the size of the primary equity markets.

These sensitivity tests show that our results on the relation between property rights protection and loan spreads are robust to a large number of alternative measures of size, structure and activity of financial intermediaries.

\subsection{Effect of property rights on loan spreads in lines of credit versus term loans}

As indicated in Section 3, banks offer firms both lines of credit (also known as "loan commitments") and/or term loans. The current literature suggests that although firms establish lines of credit to fund short-term working capital, term loans are used to finance mostly long-term investments (Strahan (1999)). Another difference is that, unlike lines of credit, term loans do not obligate the bank to provide additional credit in the future.

Lines of credit expose banks to both liquidity risk and credit risk. Banks face liquidity risks because banks promise credit to borrowers up to a certain amount on demand over the life of the contract. They expose banks to credit risk because the firm may draw down the line of credit and then default. Term lending is more straightforward because it involves credit risk but not liquidity risk.

For our purposes, the most important difference between lines of credit and term loans is that, because they are intended to provide general funds for working capital needs, lines of credit are unlikely to be backed up by specific collateral. On the other hand, term loans finance long-term investments. The acquisition of tangible assets from proceeds of term loans reduces the relative risk that bank lenders face in granting term loans rather than lines of credit. 
The analyses in previous sections combine both lines of credit and term loans. We now examine term loans and lines of credit separately. Since lines of credit expose banks to greater risk, we expect that the relation between loan contract terms and property rights protection will be more pronounced for lines of credit than the same relation for term loans.

In Table 6, we present regression results on loan spreads for separate subsamples of lines of credit and term loans. Consistent with our prediction, the sensitivity between the property rights index and bank loan spreads is significantly more pronounced for lines of credit. The coefficient on the property rights index in the loan spread regression for lines of credit is -0.18 (significant at the 1 percent level). In contrast, the coefficient on the property rights index for term loans is only -0.04 and is not significant at the conventional levels. A Wald-test for the equality of these coefficients is rejected at less than the 1-percent level. Figure 4 plots the predicted loan spreads over the entire range of property rights indexes for lines of credit and term loans separately. Consistent with the regression estimates, the figure suggests that spreads on term loans show relatively less sensitivity to changes in the property rights index than do spreads on lines of credit.

\section{Firm-level analysis}

This section examines firm-level evidence on the effect of property rights protection on loan spreads. While the country-level results reported in the previous section are robust to the inclusion of several plausible additional institutional and economic variables, unobserved heterogeneity in borrower risk characteristics may still exist across countries. Borrower characteristics, such as firm size, leverage, profitability, and the nature of assets, perhaps vary systematically across countries. ${ }^{11}$

Analysis at the firm level allows us to control for borrower characteristics and non-price loan terms. Our empirical strategy is as follows. In the first step, we estimate loan spreads as a function of observable borrower risk characteristics and non-price loan terms. We then take the country-level

\footnotetext{
${ }^{11}$ See Kumar et al. (2001) for the evidence on systematic variation in firm size across countries.
} 
fixed-effect estimates from this analysis and test if the property rights index helps explain the crosscountry variation in country residuals.

Since the LPC database does not provide data on borrower characteristics, we match (by hand) loan transactions to borrower characteristics on the Worldscope database. The firm-level sample consists of 4,222 loans during the period 1995-1999 spanning 28 countries. While we have fewer countries represented in this matched sample -28 rather than 37 in the country-level analysis - the benefit is that we have a much larger sample and there is a greater variation in the types of firms in each country.

Table 7 provides descriptive statistics for matched loan and firm data. Profitability is the ratio of net income plus depreciation divided by total assets. Debt-to-market capitalization is the ratio of total debt divided by debt plus the market value of equity. The market-to-book assets ratio is the market value of assets divided by the book value of assets. Loan spread, loan maturity and loan size are loan characteristics from the Loan Pricing Corporation's database.

We begin our investigation with firm-level regressions of the log of loan spreads on firmspecific variables and year and country dummies. The dependent variable is the natural log of basis points above the LIBOR/Prime rate charged on the loan. To control for the observable risk of the borrower in regressions determining the loan rate, we include firm size, profitability, leverage, investment intensity, the market-to-book assets ratio, and the intangible-asset-to-total asset ratio.

We include firm size because asymmetric information problems are less severe in large firms than in small firms. Large firms are more likely to be followed by multiple analysts and are more visible. Firm size is measured as the log of real assets. We include a measure of a firm's profitability since more profitable firms have lower default risk. Profitability also affects moral hazard problems and consequently loan spreads. We include leverage because it proxies for default risk and the severity of moral hazard problems (Myers (1977)). 
We include two proxies for future growth potential - investment intensity and the market-tobook assets ratio. Since managers find it more difficult to communicate credibly information about growth opportunities to lenders than they do about assets already in place, we expect adverse selection costs to be greater in growth firms. Finally, we include intangible intensity because firms with more intangible assets have a greater ability to shift wealth from creditors.

The regression results reported in Column (1) show that the firm characteristics have the predicted sign. Both firm size and profitability are negatively related to spreads suggesting that larger and more profitable firms borrow at lower interest rates. More levered firms pay higher spreads suggesting that lenders are concerned about default risk when lending to firms with high debt ratios. Growth opportunities and intangible intensity positively affect loan spreads suggesting that moral hazard problems are more severe when a firm's assets largely consist of growth options.

The regression in Column (2) includes two additional nonprice loan characteristics - loan maturity and loan size. Loan maturity is included because longer maturity loans exacerbate moral hazard problems. Short-term loans allow creditors to review their lending decisions more frequently and, if necessary, to change the terms of financing. Short-term financing also restricts the flexibility borrowers have in expropriating creditors (Diamond $(1991,1993))$. We therefore predict a positive coefficient on loan maturity. The prediction on the loan size variable is ambiguous. While larger loans increase a bank's exposure to the firm, they are also more likely to be made to better borrowers. The firm-specific variables and country dummies together explain between 54 and 61 percent of the variation in loan spreads.

The country fixed effect estimates reported in Columns (1) and (2) are useful because each estimate is an average, for a given country, of the loan spread that is left unexplained by firm and loan characteristics. We can therefore examine whether the property rights index can explain the variation in these country residuals. 
Table 9 presents the results. The dependent variable is the country fixed effect estimate from Table 8 . The country residual can only be estimated for the 28 countries for which we have both country-level and firm-level data.

The results show that the property rights index is negatively related to the country residual of the loan spreads. The coefficient is also statistically significant at the 10 percent level or better. The country-level variables in Column (4) fully explain about 49 percent of the variation in country residuals.

The results based on this two-step procedure suggest that the effect of the property rights index on the cost of bank loan financing is robust to firm-level heterogeneity in borrower risk characteristics. Together, the findings reported in the previous and the current sections convey an important policy message. Bank lenders charge significantly higher interest rates when they lend to firms in countries with less secure property rights. Thus, a country can reduce the cost of external financing for its firms by improving the level of property rights protection at the country level. The reduction in the cost of external financing associated with better protection of property rights is economically large.

\section{Ownership-control disparity, property rights and loan spreads}

The next part of our analysis examines whether firm-level corporate governance mechanisms also affect loan spreads. This analysis is motivated by concerns that organizational forms, which sometimes take the form of pyramidal ownership structures, affect the ability and incentives of the controlling shareholders to expropriate from minority shareholders and creditors.

La Porta et al. (2002b), Claessens et al. (2000), Faccio et al. (2001) show that firms in Asia and Europe are organized through pyramiding and holdings through multiple control chains that often result in a wide divergence between the ultimate owner's ownership rights and control rights. The 
ownership-control disparity affects the ability of controlling shareholders to derive private benefits of control, more easily shift risk, and expropriate corporate assets. ${ }^{12}$

In addition, the way firms are organized affects the levels of transparency and disclosure. Information asymmetries are more severe in firms with wider divergence between ownership and control rights. This severity of information problems affects a bank's ability to monitor its borrowers and to assess default risks. This section examines if ownership-control disparity affects the terms at which banks lend to firms. Do banks charge lower loan spreads to firms with better corporate governance?

To examine how cross-firm differences in corporate governance affect loan spreads, we focus on five East Asian countries and ten European countries for which we have data on ownership rights and control rights. The key variable in the analysis is a measure of ownership-control disparity constructed by Claessens et al. $(2000,2002)$ for Asia and by Faccio and Lang (2002) for Europe. ${ }^{13}$ To understand how this variable is constructed, consider a family that owns $50 \%$ of Firm A that in turn owns $30 \%$ of Firm B. This family owns $15 \%$ of the cash-flow rights of Firm B (the product of the ownership stakes along the chain) and controls $30 \%$ of control-rights of Firm B (the weakest link along the control chain). The ownership-control disparity variable is the difference between the ultimate owner's control rights and ownership rights.

Table 10 reports regression analyses on the effect of ownership-control disparity on loan spreads. The additional explanatory variables in the regression include the natural log of assets, profitability, leverage, the capital-expenditures-to-assets ratio, the market-to-book-assets ratio, and the intangible-assets-to-total-assets ratio. The regressions are estimated using firm-level data pooled across all Asian and European countries for which we have data on ownership rights and control

\footnotetext{
${ }^{12}$ See, for example, Barclay and Holderness (1989) Claessens et al. (2002), Jensen and Meckling (1976), Johnson et al. (2000), La Porta et al. (1997), Bae et al. (2002).

${ }^{13}$ Larry Lang graciously provided the ownership-control disparity data for Asia. The ownership-control disparity for Europe can be downloaded from http://www.jfe.rochester.edu/Faccio_Lang_Data.XLS.
} 
rights. The regressions include annual dummies to control for year fixed effects. Regressions in Columns (1), (3), and (5) also control for country fixed effects. The t-statistics reported are corrected for heteroscedasticity.

The results in Column (1) show a positive and significant coefficient on the ownership-control disparity consistent with banks charging higher loan spreads when lending to borrowers with greater divergence between ownership and control rights. Firm size and profitability are negatively related to spreads. Leverage is positively related to spreads only in Europe. The results on how the nature of assets affect spreads are less clear-cut.

The positive and significant coefficient on the ownership-control disparity implies that the way ownership is organized and the resulting governance structures significantly affect the cost of external financing. When firms organize ownership in ways that increase expropriation hazards and the severity of information problems, bank lenders respond by charging higher loan spreads.

In Column (2), we substitute country dummies with property rights protection. These results show that the country-level property rights protection index is significantly negatively related to loan spreads. The ownership-control disparity variable continues to remain positive and significant. This suggests that both firm-level corporate governance and country-level protection of property rights are important in determining loan spreads.

However, the magnitude and significance of the coefficient on the property rights index variable is much larger than that on the ownership-control disparity variable. In unreported regressions that exclude country fixed effects, we find that the $\mathrm{R}^{2}$ is about 8 percent when the ownership-control disparity is included together with the control variables (without the country dummies). The $\mathrm{R}^{2}$ jumps to 45 percent when we include property rights protection together with the control variables. In addition, the sensitivity of predicted loan spreads to changes in ownershipcontrol disparity within a country is much smaller than the sensitivity to changes in property rights 
index across countries. ${ }^{14}$ Overall, these results suggest that the country-level property rights index explains much more of the variation in loan spreads compared to that explained by firm-level governance variables.

Faccio et al. (2001) argue that ownership-control disparity has very different effects on the ability of controlling shareholders to expropriate in East Asia than in Western Europe. According to these authors, European firms are more transparent and multiple large owners in Europe limit expropriation of minority shareholders by the controlling shareholders. Firms in Asia are less transparent and "other large owners typically collude with the controlling shareholder in expropriating minority shareholders".

We therefore examine borrowers in Asia and Europe separately. Columns (3) and (4) report regression results for the Asian countries. Columns (5) and (6) report regression results for European countries. Consistent with the arguments by Faccio et al. (2001), we find that the ownership-control disparity variable has a much stronger effect on loan spreads in Asia. By contrast, the effect of the ownership-control disparity on loan spreads is much weaker in Europe. The F-test shows that the estimated coefficient on ownership-control disparity in Europe is significantly smaller than that for Asia (p-value of 0.025). In both Asia and Europe, more secure property rights index results in smaller loan spreads. Also, the property rights index has a much larger impact on loan spreads relative to the impact of the ownership-control disparity on loan spreads in both Asia and Europe.

\section{Conclusion}

In this paper, we investigate how the protection of property rights affects bank loan spreads. Some countries provide stronger protection for private property rights than do other countries. The rights that lenders have are likely to be better enforced in countries with stronger protection of

\footnotetext{
${ }^{14}$ Ownership-control disparity and the property rights index are uncorrelated; the correlation coefficient is 0.05
} with a p-value of 0.86 . 
property rights. We ask if cross-country differences in property rights protection affect bank loan spreads.

The findings suggest that differences in property rights protection translate into large differences in loan pricing between firms and their lenders. In countries that provide weak property rights protection, loan spreads are larger. To test the robustness of these results, we also control for heterogeneity in borrower risk characteristics using firm-level regressions. We find that the property rights index is significantly related to loan spreads even after controlling for firm-level differences in borrower risk characteristics.

Finally, we examine if the way ownership is organized in several countries in Asia and Europe affects loan spreads charged to borrowers in these countries. We find that a greater divergence between ownership rights and control rights indeed results in higher loan spreads. However, the effect of property rights on loan spreads dominates that of the ownership-control disparity on loan spreads.

Based on the evidence presented here, we offer two policy implications. The first implication is that by improving property rights protection, a country can expect to see a large reduction in its cost of external financing. While we are not the first to reach this conclusion, our evidence is more direct and it is based on a cross-country sample of actual loan transactions. The second policy implication is about the importance of improving country-level institutions in reducing expropriation and contracting risk. Improving property rights protection at the country-level has a large impact on bank loan spreads. Improving firm-level corporate governance mechanisms matters too, but the effects are second order. 


\section{References}

Acemoglu, D., Johnson, S., Robinson, J., 2001. The colonial origins of comparative development: An empirical investigation. American Economic Review 91(5), 1369-1401.

Bae, K.-H., Kang, J.-K., Kim, J.-M., 2002. Tunneling or Value Added: Evidence from Mergers by Korean Business Groups, Journal of Finance 62, 2695-2740.

Barclay, M., Holderness, C., 1989. Private benefits and control of public corporations. Journal of Financial Economics, 371-395.

Barth, J.R., Caprio, G., Levine, R., 2003. Bank regulation and supervision: What works best? Forthcoming, Journal of Financial Intermediation.

Beck, T., Demirgüç-Kunt, A., Levine, R., 1999. A new database on financial development and structure. Working paper, World Bank and the University of Minnesota.

Besley, T., 1995. Property rights and investment incentives: Theory and evidence from Ghana. Journal of Political Economy 103, 903-937.

Claessens, S., Djankov, S., Lang, L.H.P., 2000. The separation of ownership and control in East Asian Corporations. Journal of Financial Economics 58, 81-112.

Claessens, S., Djankov, S., Fan, J.P.H., Lang, L.H.P., 2002. Disentangling the incentive and entrenchment effects of large shareholdings. Journal of Finance 57, 2741-2771.

Diamond, D.W., 1991. Debt maturity and liquidity risk. Quarterly Journal of Economics 106, 709-737.

Diamond, D.W., 1993. Seniority and maturity of debt contracts. Journal of Financial Economics 33, 341-368.

Demirgüç-Kunt, A., Maksimovic, V., 1998. Law, Finance, and Firm Growth, Journal of Finance 53, 2107-2137.

Demirgüç-Kunt, A., Maksimovic, V., 1999. Institutions, financial markets, and firm debt maturity, Journal of Financial Economics 54, 295-336.

Durnev, A., Kim, E.H., 2003. To steal or not to steal: Firm attributes, legal environment, and valuation. Working paper, University of Michigan.

Esty, B.C., 2002. When do foreign banks finance domestic investment? New evidence on the importance of legal and financial systems. Working paper, Harvard Business School.

Esty, B.C., Megginson, W.L., 2003. Creditor rights, enforcement, and debt ownership structure: Evidence from the global syndicate loan market. Journal of Financial and Quantitative Analysis 38, 37-59.

Faccio, M., Lang, L.H.P., Young, L., 2001. Dividends and expropriation. American Economic Review 91, 54-78. 
Faccio, M., Lang, L.H.P., 2002. The ultimate ownership of western European corporations. Journal of Financial Economics 65, 365-395.

Jensen, M.C., Meckling, W., 1976. Theory of the firm: managerial behavior, agency costs and capital structure. Journal of Financial Economics 3, 305-360.

Johnson, S., La Porta, R., Lopez-de-Silanes, F., Shleifer, A., 2000. Tunneling. American Economic Review Papers and Proceedings 90, 22-27.

Kumar, K., Rajan, R., Zingales, L., 2001. What determines firm size? Working paper, University of Chicago.

La Porta, R., Lopez-de-Silanes, F., Shleifer, A., Vishny, R.W., 1997. Legal Determinants of External Finance. Journal of Finance 52, 1131-1150.

La Porta, R., Lopez-de-Silanes, F., Shleifer, A., Vishny, R.W., 1998. Law and Finance. Journal of Political Economy 106, 1113-1155.

La Porta, R., Lopez-de-Silanes, F., Shleifer, A., Vishny, R.W., 2000. Investor Protection and Corporate Governance, Journal of Financial Economics 58, 3-27.

La Porta, R., Lopez-de-Silanes, F., Shleifer, A., 2002a. What works in securities law? Working paper, Harvard University, Yale University, and Harvard University.

La Porta, R., Lopez-de-Silanes, F., Shleifer, A., Vishny, R.W., 2002b. Investor Protection and Corporate valuation. Journal of Finance 57, 1147-1170.

La Porta, R., Lopez-de-Silanes, F., Shleifer, A., 2002c. Government ownership of banks. Journal of Finance, February.

Levine, R., 1999. Law, finance and economic growth. Journal of Financial Intermediation 8, 8-35.

Levine, R., Beck, T., Loyaza, N., 2000. Financial intermediation and growth: causality and causes. Journal of Monetary Economics 46, 31-77.

Mauro, P., 1995. Corruption and growth. Quarterly Journal of Economics 110, 681-712.

Morck, R., Yeung, B., Yu, W., 2000. The information content of stock markets: why do emerging markets have synchronous stock price movements? Journal of Financial Economics 58, 215-260.

Myers, S.C., 1977. Determinants of corporate borrowing. Journal of Financial Economics 5, 147-175.

Rajan, R., Zingales, L., 1998. Financial dependence and growth. American Economic Review 88, 559586.

Strahan, P.E., 1999. Borrower risk and the price and nonprice terms of bank loans. Working paper, Federal Reserve Bank of New York.

Stulz, R., Williamson, R., 2002. Culture, openness, and finance. Journal of Financial Economics forthcoming. 
Figure 1: Relative Importance of different forms of financing for 49 countries

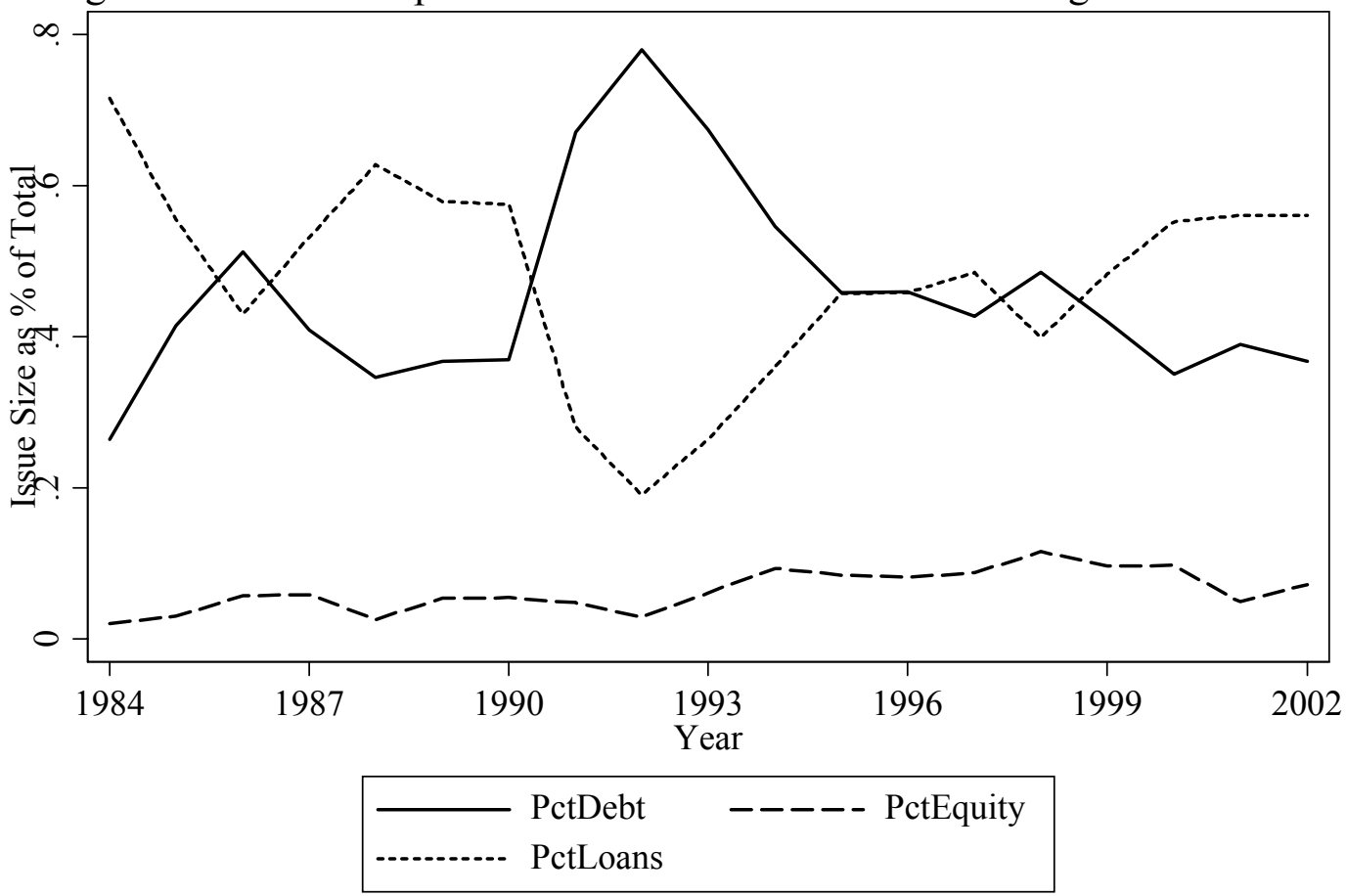

Figure 2: Property Rights Index versus Loan Spread

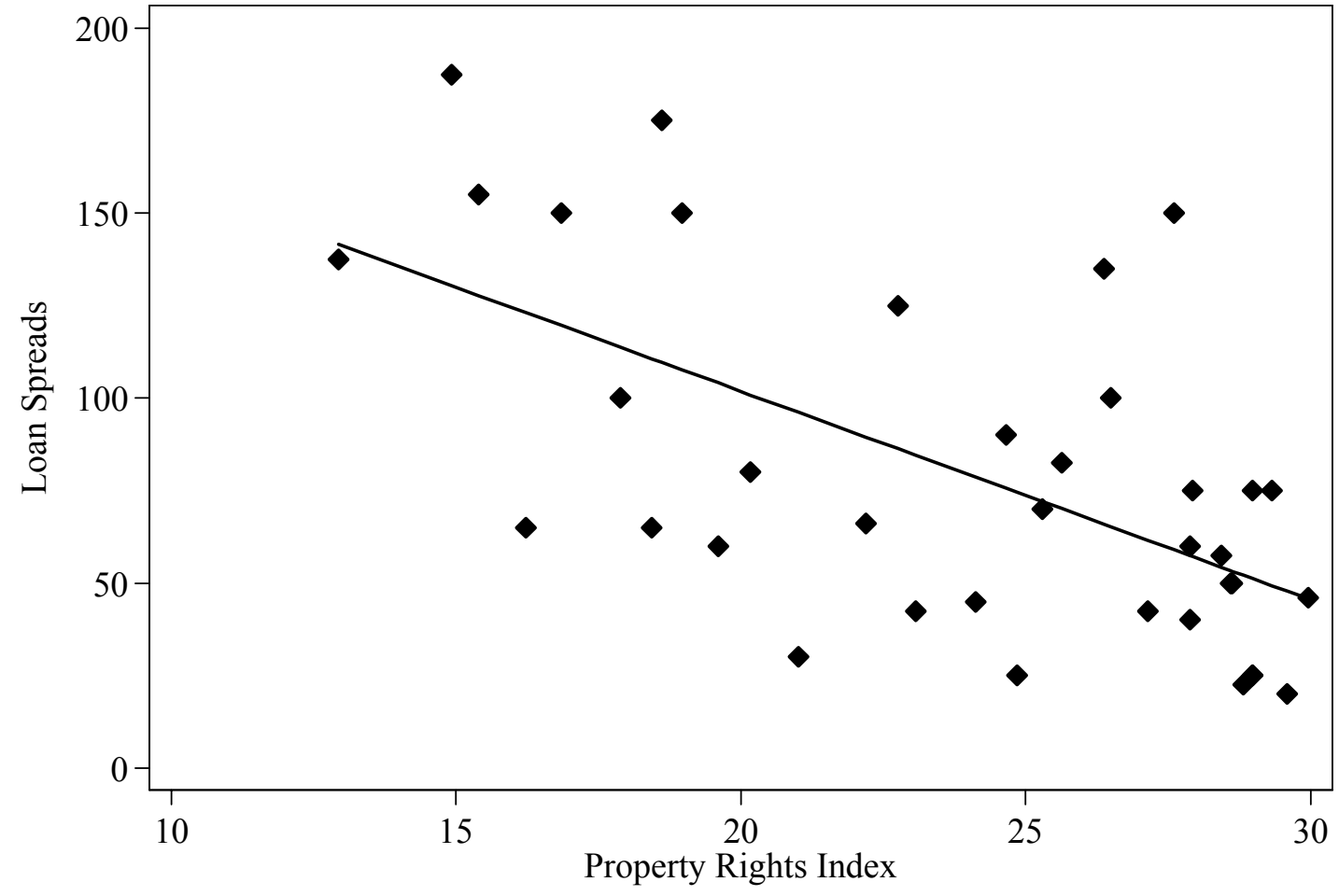


Figure 3: Predicted Loan Spreads and Property Rights Protection

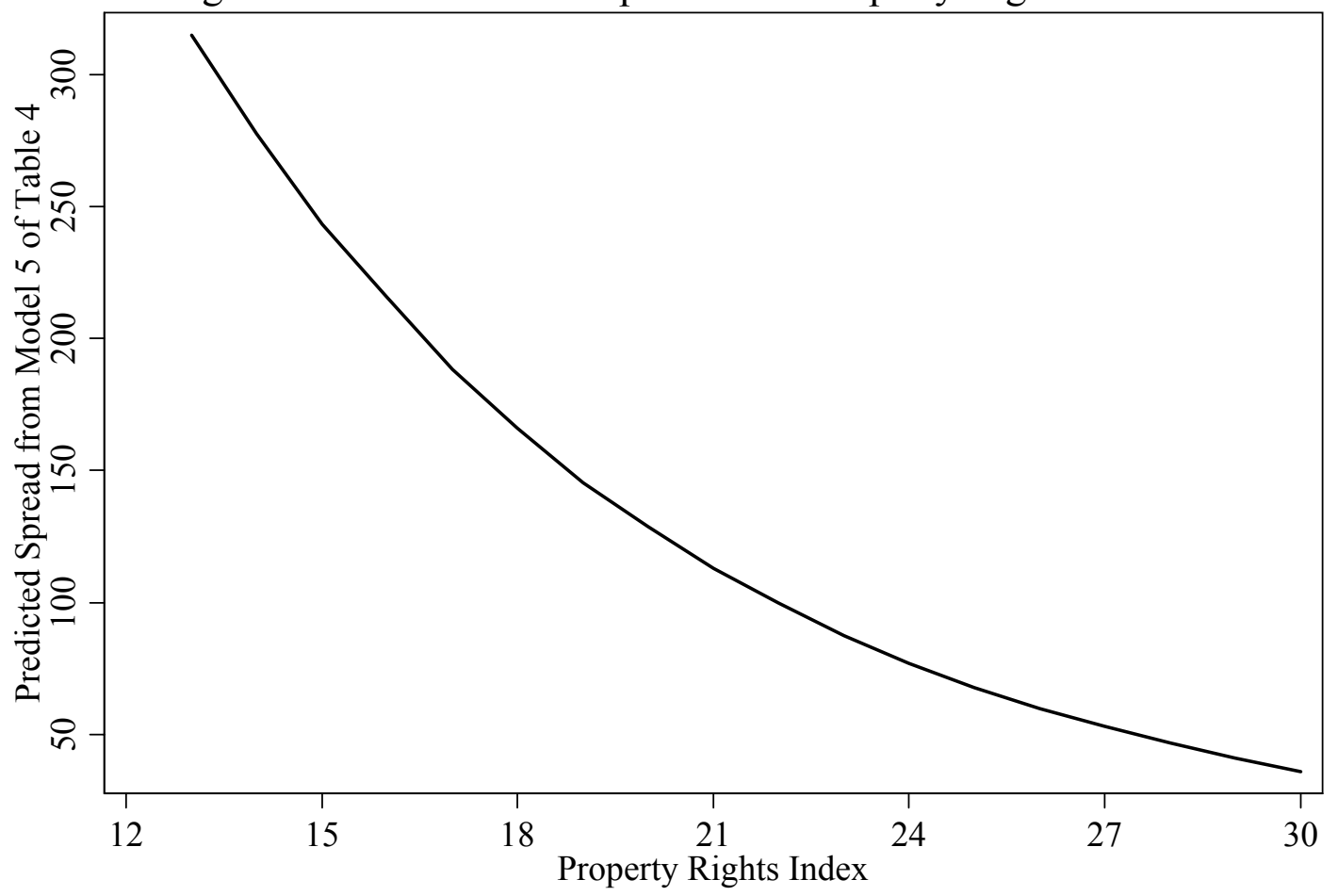

Figure 4: Predicted Loan Spreads and Property Rights by Loan Type

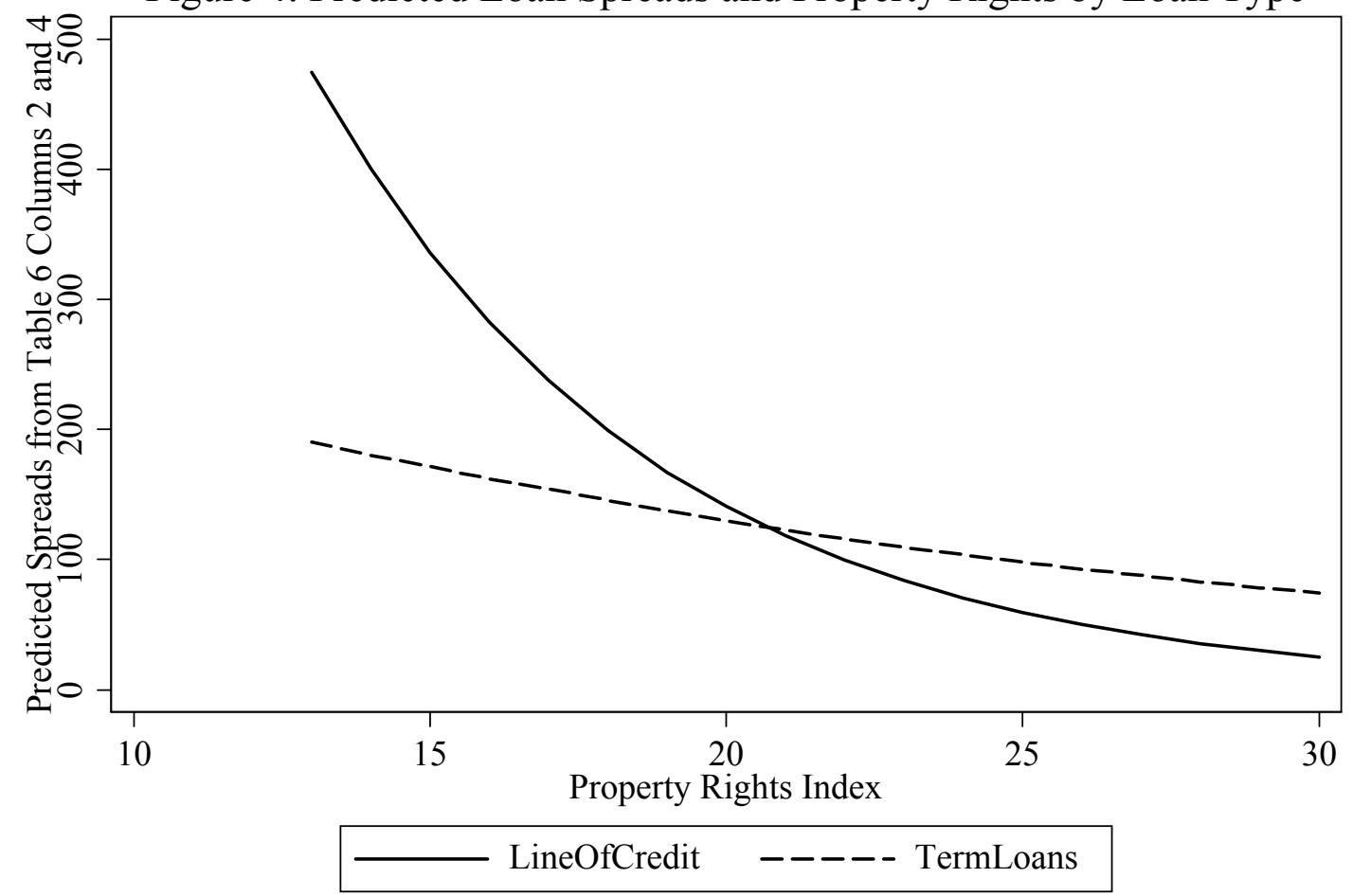




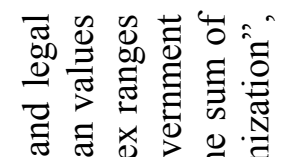

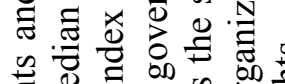

앨

$\exists$ o

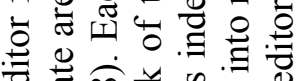

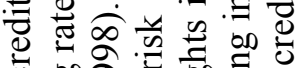

ठั 00 ล :

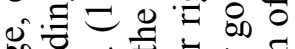

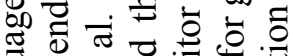

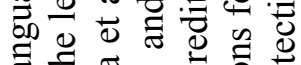

코 푼

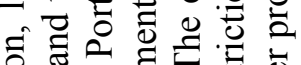

.0.

ग

ค ี

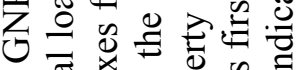

ฐ

글 0 은

ซึ.

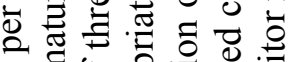

की

बैं ची ठु

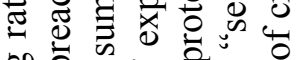

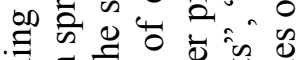

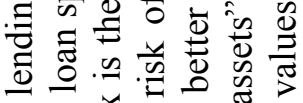

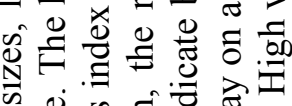

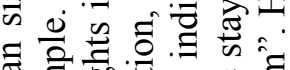

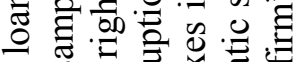

क

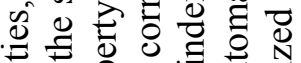

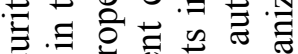

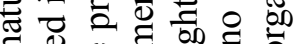

$\exists$ \&

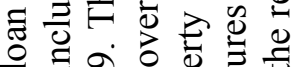

‥ 2 品

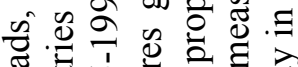

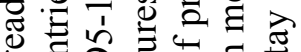

के

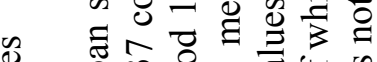

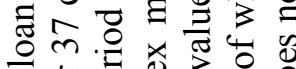

궁

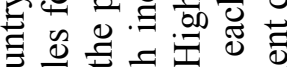

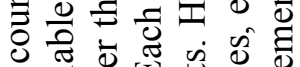

늏

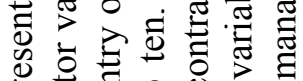

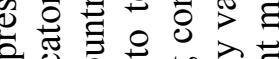

ప.

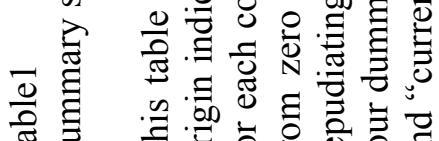

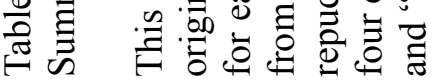

胥泀 $000000000-00-00000000$

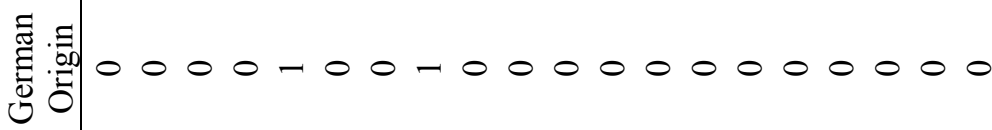

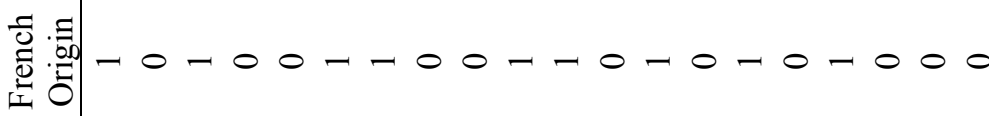

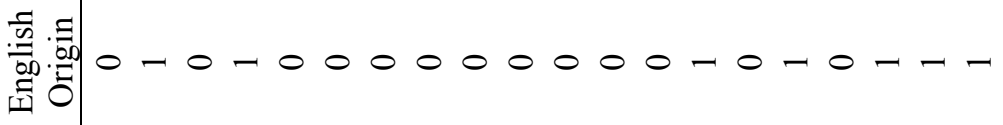

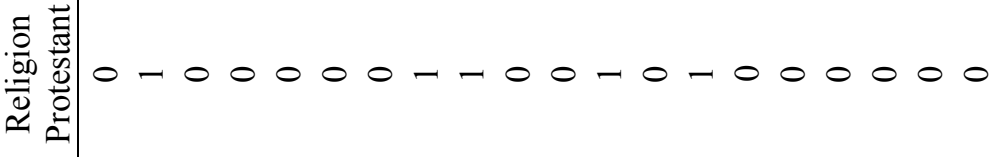

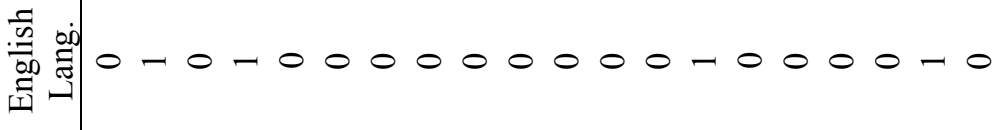

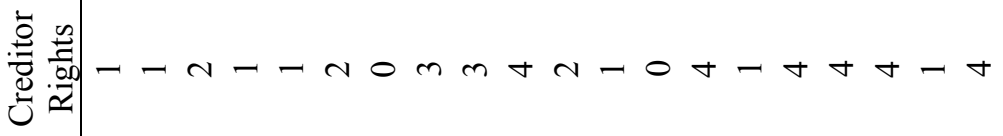

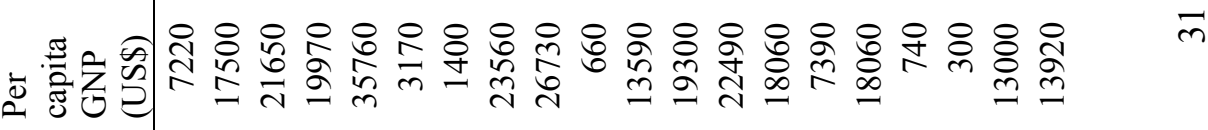

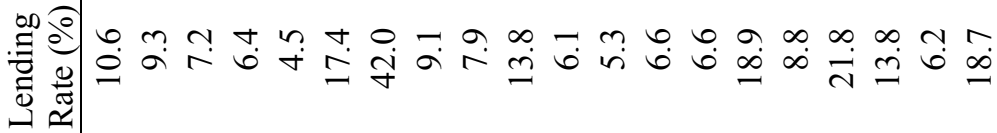

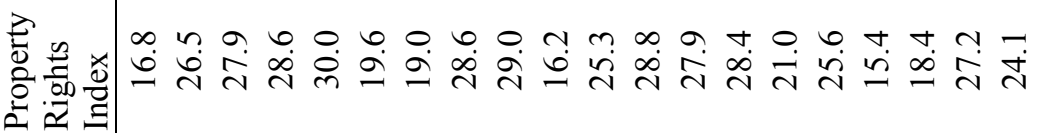

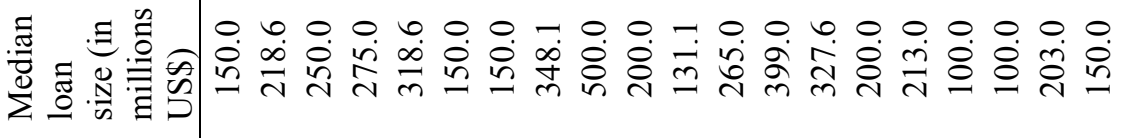

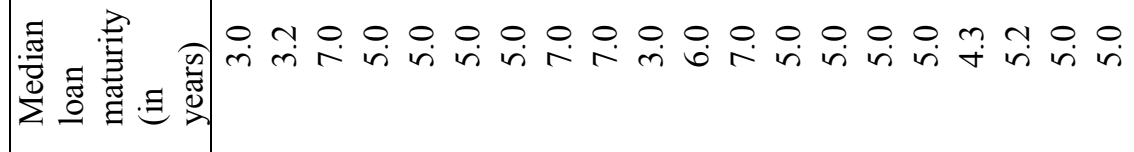

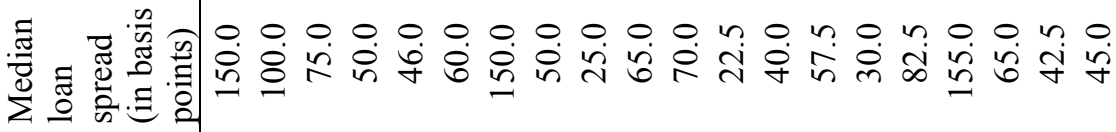

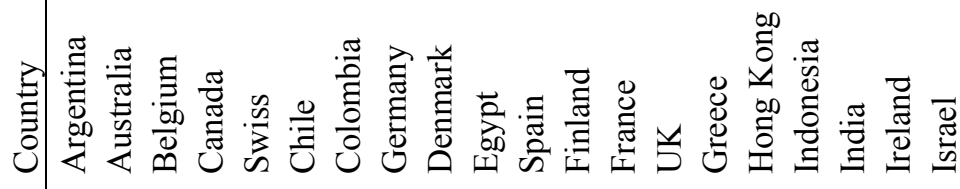




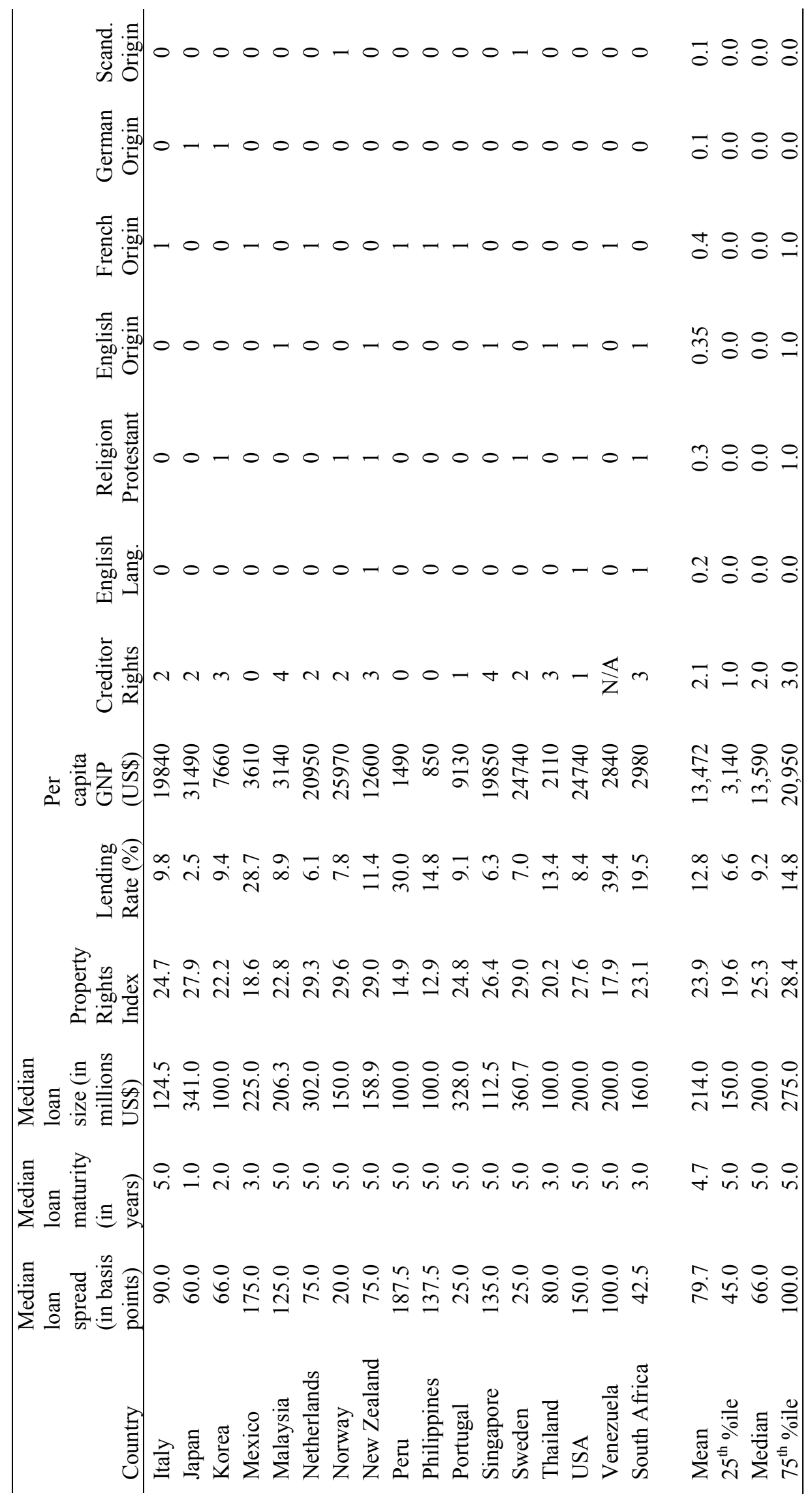


Table 2

Loan spreads and property rights protection

The table presents summary statistics of country median loan spreads (in basis points) for countries with weak, medium, and strong property rights protection. Property rights protection categories are based on the property rights index, which is a sum of three indexes from La Porta et al. (1998), each ranging from zero to ten. Each index measures government corruption, the risk of expropriation by government, and the risk of the government repudiating contracts. High values of the property rights indexes indicate better protection of property rights. The summary statistics presented below are for the cross-country data on median loan spreads. The table also reports descriptive statistics for country median loan spreads for lines of credit and term loans separately.

\begin{tabular}{|c|c|c|c|c|}
\hline & \multirow{2}{*}{$\begin{array}{c}\text { All } \\
\text { countries }\end{array}$} & \multicolumn{3}{|c|}{ Property rights protection } \\
\hline & & Weak & Medium & Strong \\
\hline \multicolumn{5}{|c|}{ A. Loan spreads for all loans (in basis points) } \\
\hline Mean & 79.7 & 112.9 & 81.1 & 47.8 \\
\hline $25^{\text {th }}$ percentile & 45.0 & 65.0 & 43.8 & 25.0 \\
\hline Median & 66.0 & 118.8 & 76.3 & 50.0 \\
\hline $75^{\text {th }}$ percentile & 100.0 & 152.5 & 112.5 & 60.0 \\
\hline \multicolumn{5}{|c|}{ B. Lines of credit versus term loans } \\
\hline \multicolumn{5}{|c|}{ B.1 Percent of loans that are lines of credit } \\
\hline$\%$ lines of credit & $55.9 \%$ & $30.4 \%$ & $59.1 \%$ & $76.1 \%$ \\
\hline \multicolumn{5}{|c|}{ B.2 Loan spreads for lines of credit (in basis points) } \\
\hline Mean & 79.8 & 134.8 & 79.6 & 33.5 \\
\hline $25^{\text {th }}$ percentile & 26.3 & 72.0 & 42.5 & 22.5 \\
\hline Median percentile & 57.1 & 85.0 & 60.5 & 25.0 \\
\hline $75^{\text {th }}$ percentile & 83.1 & 200.0 & 90.6 & 40.0 \\
\hline \multicolumn{5}{|c|}{ B.3 Loan spreads for term loans (in basis points) } \\
\hline Mean & 103.8 & 117.2 & 102.7 & 92.5 \\
\hline $25^{\text {th }}$ percentile & 60.0 & 70.0 & 52.5 & 35.0 \\
\hline Median & 100.0 & 125.0 & 87.5 & 100.0 \\
\hline $75^{\text {th }}$ percentile & 150.0 & 158.1 & 130.0 & 125.0 \\
\hline
\end{tabular}




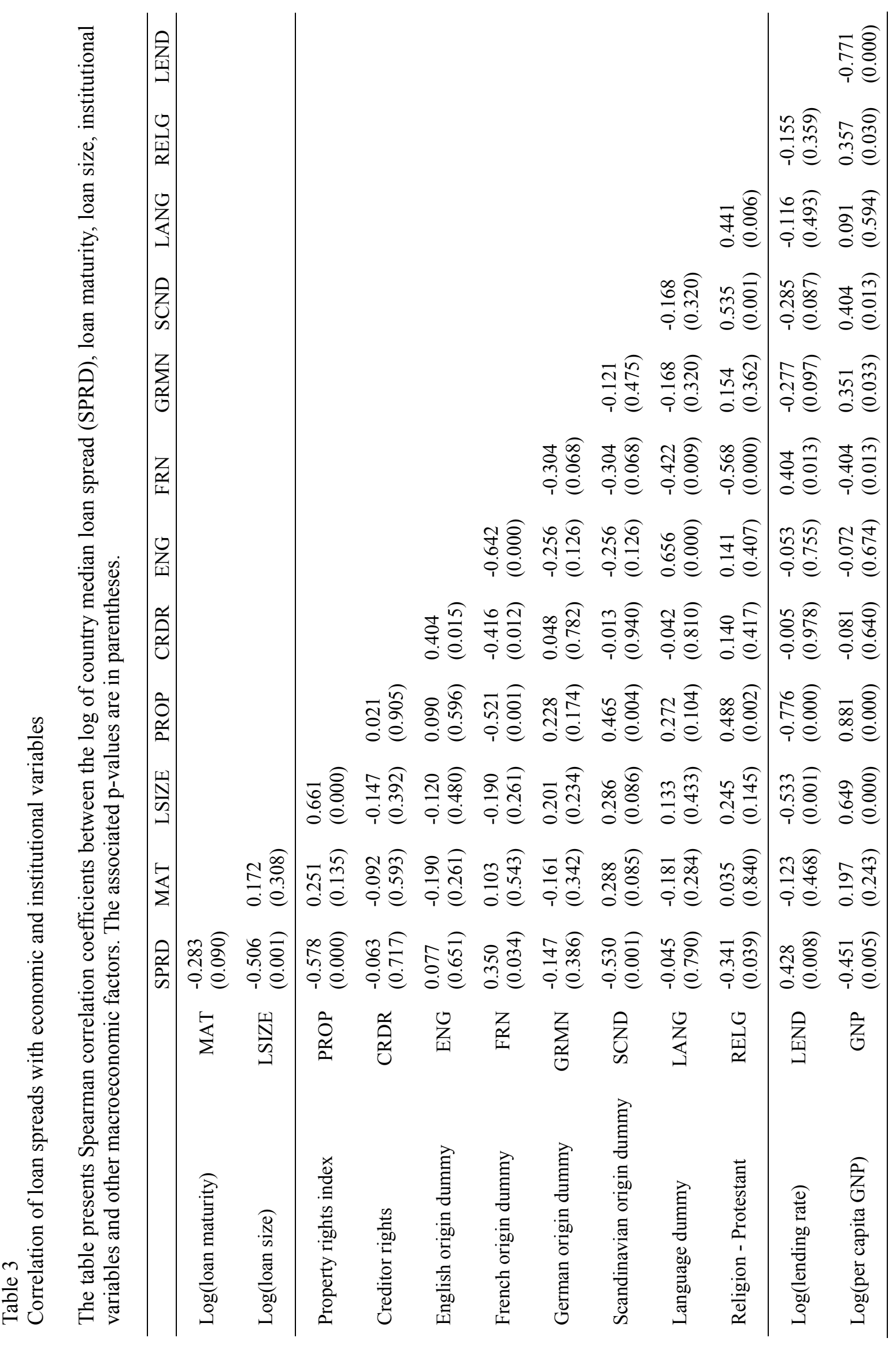


Table 4

Country level regression - loan spreads and property rights protection

The table presents results from country level regressions of country median loan spreads. The sample includes 37 countries. The dependent variable is the median values of loan spreads of each country for the period 1995-1999. Independent variables include the natural logarithm of the median lending rate and $\log$ of per capita GNP, property rights index, creditor rights index, log of median loan maturity and $\log$ of median loan size. Numbers in parentheses are t-statistics corrected for heteroscedasticity. ${ }^{* * *}$ Significant at the 1 percent level. ${ }^{* *}$ Significant at the 5 percent level. ${ }^{*}$ Significant at the 10 percent level.

\begin{tabular}{|c|c|c|c|c|c|}
\hline & $(1)$ & $(2)$ & (3) & (4) & $(5)$ \\
\hline Log of lending rate & $\begin{array}{l}0.220 \\
(1.2)\end{array}$ & $\begin{array}{l}0.438 \\
(2.8)^{* * *}\end{array}$ & $\begin{array}{l}-0.025 \\
(-0.1)\end{array}$ & $\begin{array}{l}0.031 \\
(0.1)\end{array}$ & $\begin{array}{l}0.053 \\
(0.2)\end{array}$ \\
\hline Log of per capita GNP & $\begin{array}{l}-0.137 \\
(-1.4)\end{array}$ & & & $\begin{array}{l}0.194 \\
(1.4)\end{array}$ & $\begin{array}{c}0.261 \\
(1.8)^{*}\end{array}$ \\
\hline Creditor rights index & & $\begin{array}{l}-0.011 \\
(-0.2)\end{array}$ & & $\begin{array}{c}0.02 \\
(0.3)\end{array}$ & $\begin{array}{l}0.050 \\
(0.7)\end{array}$ \\
\hline Property rights index & & & $\begin{array}{c}-0.073 \\
(-3.4)^{* * *}\end{array}$ & $\begin{array}{l}-0.114 \\
(-3.3)^{* * *}\end{array}$ & $\begin{array}{c}-0.127 \\
(-3.5)^{* * *}\end{array}$ \\
\hline English language dummy & & & & & $\begin{array}{l}0.524 \\
(2.1)^{* *}\end{array}$ \\
\hline Protestant religion dummy & & & & & $\begin{array}{l}-0.331 \\
(-1.6)\end{array}$ \\
\hline Constant & $\begin{array}{l}4.913 \\
(4.0)^{* * *}\end{array}$ & $\begin{array}{l}3.199 \\
(7.9)^{* * *}\end{array}$ & $\begin{array}{c}6.015 \\
(7.3)^{* * *}\end{array}$ & $\begin{array}{c}5.076 \\
(4.3)^{* * *}\end{array}$ & $\begin{array}{l}4.678 \\
(3.4)^{* * *}\end{array}$ \\
\hline Observations & 37 & 36 & 37 & 36 & 36 \\
\hline R-squared & 0.22 & 0.17 & 0.33 & 0.35 & 0.44 \\
\hline
\end{tabular}




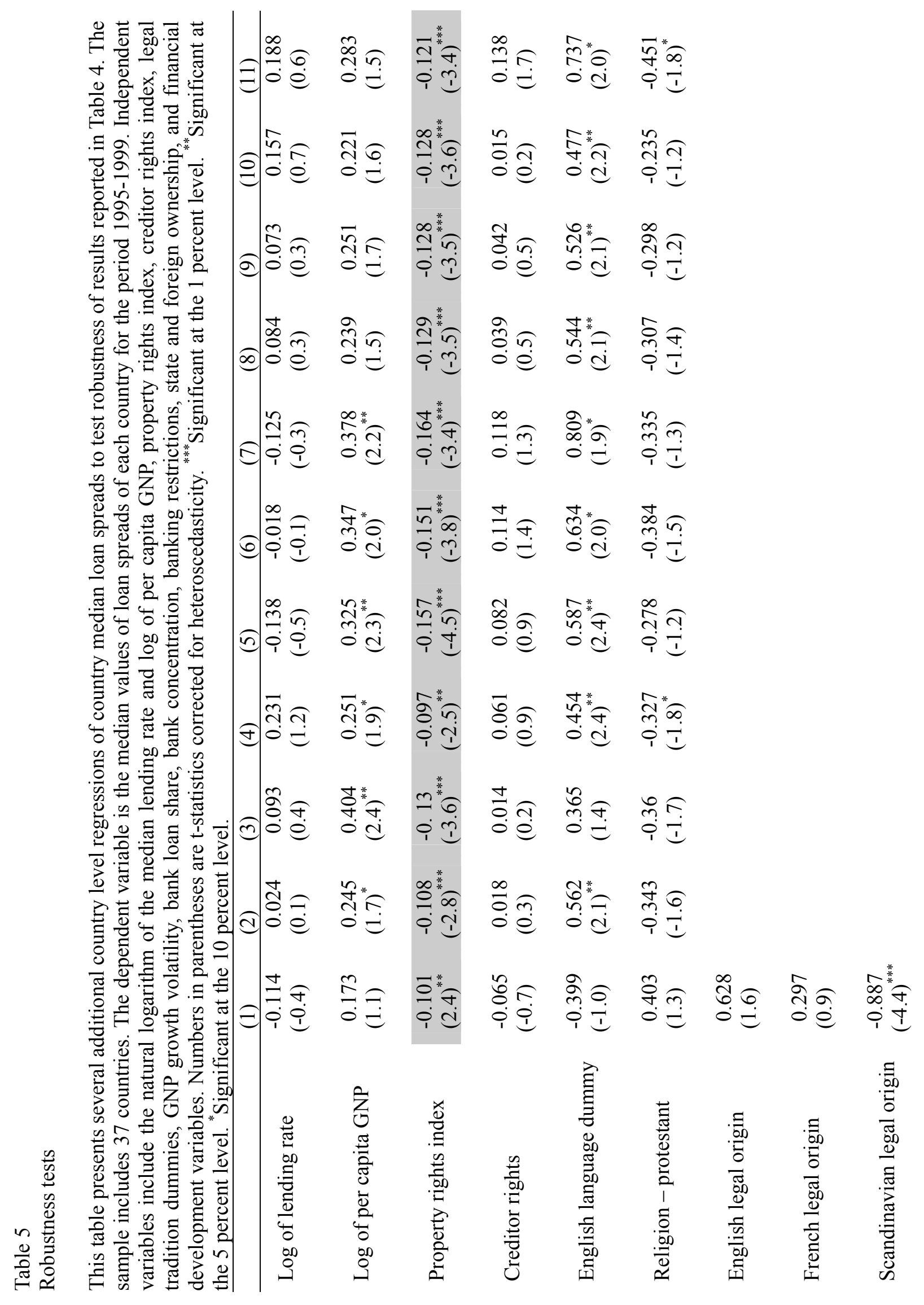


כ)

(્)

尺

6

(5) $\quad \stackrel{0}{0}$

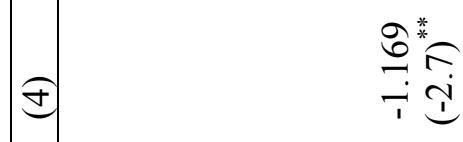

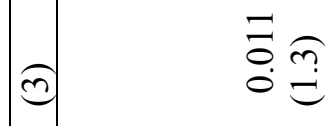

ฮิ $\stackrel{0}{*} \stackrel{0}{0}$

戸

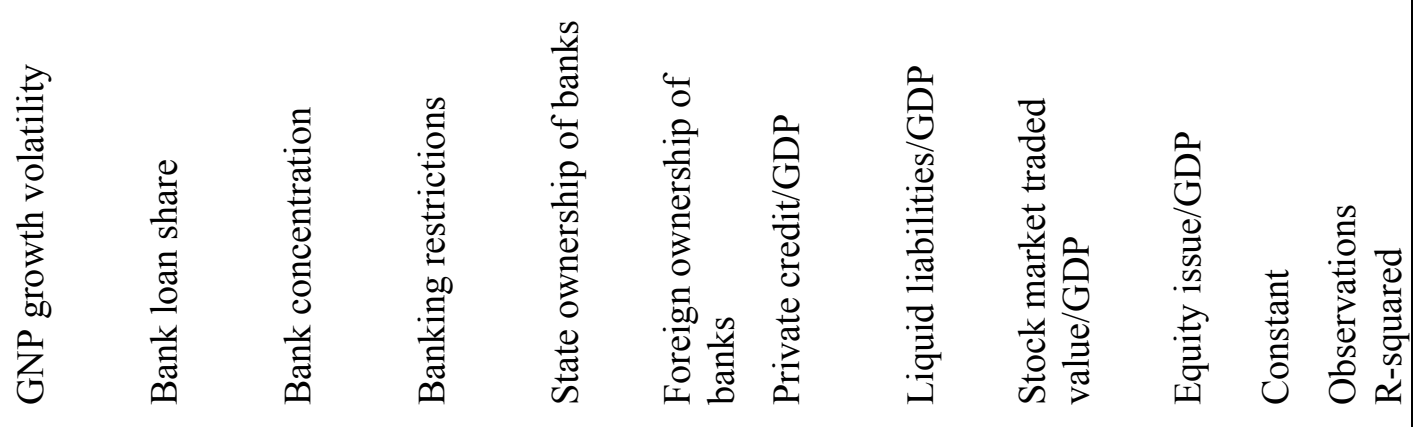


Table 6

Loan spreads and property rights protection by loan type

The table presents the results of cross-sectional regression of 37 countries for lines of credit and term loan separately. The dependent variables are the median values of loan spread of each country for the period 1995-1999. The independent variables include the median values of lending rate level and log of per capita GNP, creditor rights index, property rights index, legal origin dummies, and religion and language dummies. Numbers in parentheses are the t-statistics corrected for heteroscedasticity. ${ }^{* * *}$ Significant at the 1 percent level. ${ }^{* *}$ Significant at the 5 percent level. ${ }^{*}$ Significant at the 10 percent level.

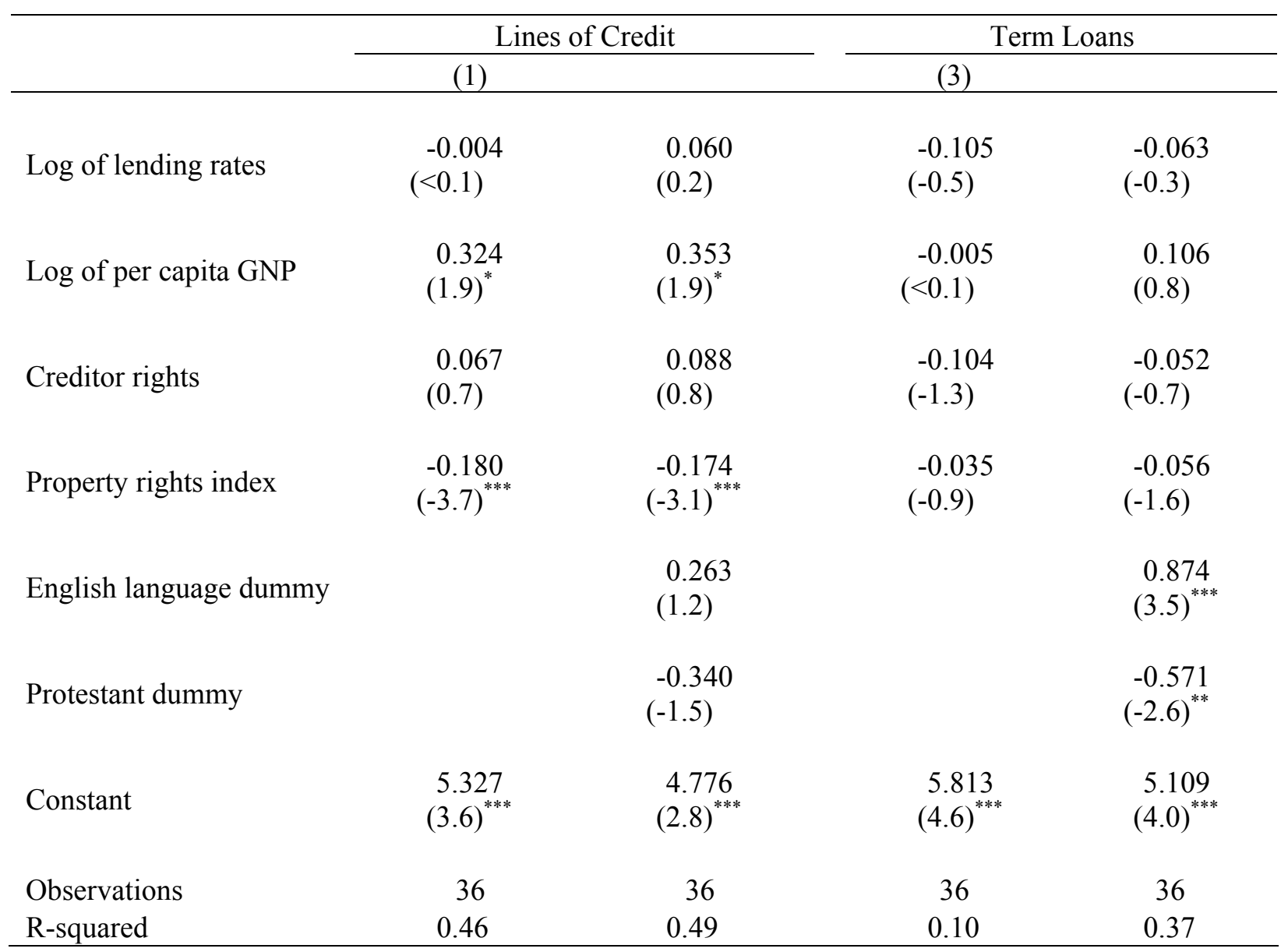


Table 7

Firm level analysis - summary statistics for loan borrowers

This table presents descriptive statistics on borrowers with data on the WorldScope database. The sample includes 4,222 loans spanning 28 countries. Profitability is defined as the ratio of net income plus depreciation divided by total assets. Debt to market capitalization is defined as the ratio of total debt divided by debt plus market value of equity. Market to book assets ratio is defined as market value of assets divided by book value of assets. Capital expenditure to assets ratio is capital expenditures divided by total assets. Intangible to total assets ratio is defined as the ratio of intangibles to total assets. Loan spread, loan maturity and loan size are loan characteristics from the Loan Pricing Corporation's database.

\begin{tabular}{lrrrrr}
\hline & & Mean & $\begin{array}{c}\text { 25th } \\
\text { percentile }\end{array}$ & Median & $\begin{array}{c}\text { 75th } \\
\text { percentile }\end{array}$ \\
\hline Total assets (in US\$) & 4,222 & 3415.61 & 160.52 & 576.90 & 2005.13 \\
Profitability & 4,222 & 0.12 & 0.08 & 0.12 & 0.17 \\
Debt to market capitalization & 4,222 & 0.30 & 0.12 & 0.26 & 0.44 \\
Market to book assets ratio & 4,222 & 1.56 & 0.85 & 1.17 & 1.75 \\
Capital expenditure to assets ratio & 4,222 & 0.07 & 0.03 & 0.05 & 0.09 \\
Intangible to total assets ratio & 4,222 & 0.17 & 0.02 & 0.10 & 0.25 \\
Loan spread (in basis points) & 4,222 & 146.23 & 50.00 & 125.00 & 225.00 \\
Loan maturity (in years) & 3,845 & 3.66 & 1.50 & 3.64 & 5.00 \\
Loan size (in million US\$) & 4,222 & 269.02 & 25.00 & 100.00 & 250.00 \\
\hline
\end{tabular}


Table 8

Firm-level regressions of loan spreads on firms and loan characteristics with country fixed effects

The table presents results from country fixed effect regressions of the natural log of loan spreads on firm and loan characteristics. The sample includes 4,222 loan transactions from 28 countries. The dependent variable is the natural log of loan spreads. Independent variables include borrowing firm's log of total assets, the profitability ratio (net income plus depreciation divided by total assets), leverage (total debt divided by market capitalization), capital expenditure to assets ratio, market-to-book assets ratio, and intangible assets ratio (intangible assets divided by total assets). The regression specification in column (2) also includes log of loan maturity and log of loan size. Both specifications include country dummy variables and year dummy variables. ${ }^{* * *}$ Significant at the 1 percent level. ${ }^{* *}$ Significant at the 5 percent level. ${ }^{*}$ Significant at the 10 percent level.

\begin{tabular}{|c|c|c|}
\hline & $(1)$ & $(2)$ \\
\hline Log of assets & $\begin{array}{c}-0.283 \\
(-44.3)^{* * *}\end{array}$ & $\begin{array}{c}-0.126 \\
(-11.8)^{* * *}\end{array}$ \\
\hline Profitability & $\begin{array}{l}-0.797 \\
(-6.5)^{* * *}\end{array}$ & $\begin{array}{l}-0.688 \\
(-6.3)^{* * *}\end{array}$ \\
\hline Debt to market capitalization ratio & $(24.1)^{* * *}$ & $\begin{array}{c}1.107 \\
(22.8)^{* * *}\end{array}$ \\
\hline Capital expenditure to assets ratio & $\begin{array}{l}0.473 \\
(3.6)^{* * *}\end{array}$ & $\begin{array}{l}0.601 \\
(5.0)^{* * *}\end{array}$ \\
\hline Market to book assets ratio & $\begin{array}{l}0.037 \\
(4.5)^{* * *}\end{array}$ & $\begin{array}{c}0.034 \\
(4.4)^{* * *}\end{array}$ \\
\hline Intangible to total assets ratio & $\begin{array}{l}0.392 \\
(6.9)^{* * *}\end{array}$ & $\begin{array}{c}0.508 \\
(9.4)^{* * *}\end{array}$ \\
\hline Log of loan maturity & & $\begin{array}{c}0.081 \\
(5.7)^{* * *}\end{array}$ \\
\hline Log of loan size & & $\begin{array}{c}-0.219 \\
(-20.9)^{* * *}\end{array}$ \\
\hline Constant & $\begin{array}{c}5.7 \\
(101.7)^{* * *}\end{array}$ & $\begin{array}{c}7.442 \\
(110.7)^{* * *}\end{array}$ \\
\hline Year dummies & Yes & Yes \\
\hline \multicolumn{3}{|l|}{ Country fixed effects } \\
\hline $\begin{array}{l}\text { ARG } \\
\text { AUS } \\
\text { CAN } \\
\text { CHL }\end{array}$ & $\begin{array}{l}1.341^{* * *} \\
0.408^{* *} \\
0.582^{* * *} \\
2.278^{* * *}\end{array}$ & $\begin{array}{l}-0.717^{* * *} \\
-1.489^{* * *} \\
-1.260^{* * *} \\
-0.807^{* * *}\end{array}$ \\
\hline
\end{tabular}




\begin{tabular}{lcc}
\hline & $(1)$ & $(2)$ \\
\hline DNK & -0.060 & $-2.139^{* * *}$ \\
FIN & 0.062 & $-2.109^{* * *}$ \\
FRA & $0.484^{* * * *}$ & $-1.716^{* * *}$ \\
DEU & -0.024 & $-2.028^{* * *}$ \\
GRC & 0.000 & 0.000 \\
HKG & $1.269^{* * *}$ & $-0.949^{* * *}$ \\
IND & $1.204^{* * *}$ & $-1.498^{* * *}$ \\
IDN & $2.866^{* * *}$ & $-0.194^{*}$ \\
IRL & 0.190 & $-1.384^{* * *}$ \\
ISR & 0.111 & $-2.074^{* * *}$ \\
ITA & $2.101^{* * *}$ & $-1.321^{* * *}$ \\
JPN & $2.047^{* * *}$ & $-0.728^{* * *}$ \\
MEX & $2.019^{* * *}$ & $-0.254^{* *}$ \\
NLD & 0.055 & $-1.740^{* * *}$ \\
NOR & $0.240^{* *}$ & $-1.873^{* * *}$ \\
PER & $2.174^{* * *}$ & 0.000 \\
PHL & 0.000 & $-1.981^{* * *}$ \\
KOR & $2.179^{* * *}$ & $-1.192^{* * *}$ \\
ESP & $1.504^{* * *}$ & $-1.383^{* * *}$ \\
SWE & 0.126 & $-2.009^{* * *}$ \\
CHE & 0.174 & $-1.735^{* * *}$ \\
THA & $1.262^{* * *}$ & $-1.113^{* * *}$ \\
USA & $0.557^{* * *}$ & $-1.339^{* * *}$ \\
GBR & -0.016 & $-1.740^{* * *}$ \\
Observations & & 3845 \\
R-squared & 4222 & 0.61 \\
\hline
\end{tabular}


Table 9

Country fixed effect estimates of loan spreads as a function of property rights protection

The dependent variable is the estimated country fixed effects from Table 8 . The independent variables include the median values of lending rate level and log of per capita GNP, property rights index, creditor rights index, English-speaking-country dummy, and a Christian-country dummy. Numbers in parentheses are t-statistics corrected for heteroscedasticity. ${ }^{* * *}$ Significant at the 1 percent level. ${ }^{* *}$ Significant at the 5 percent level. ${ }^{*}$ Significant at the 10 percent level.

\begin{tabular}{|c|c|c|c|c|}
\hline & \multicolumn{2}{|c|}{$\begin{array}{l}\text { Country fixed effects from } \\
\text { Model (1) of Table } 8\end{array}$} & \multicolumn{2}{|c|}{$\begin{array}{l}\text { Country fixed effects from } \\
\text { Model (2) of Table } 8\end{array}$} \\
\hline & $(1)$ & $(2)$ & $(3)$ & $(4)$ \\
\hline Log of lending rate & $\begin{array}{l}-0.391 \\
(-0.6)\end{array}$ & $\begin{array}{l}-0.316 \\
(-0.5)\end{array}$ & $\begin{array}{r}0.13 \\
(0.3)\end{array}$ & $\begin{array}{l}0.216 \\
(0.4)\end{array}$ \\
\hline Log of per capita GNP & $\begin{array}{l}0.243 \\
(1.1)\end{array}$ & $\begin{array}{l}0.233 \\
(1.0)\end{array}$ & $\begin{array}{l}0.224 \\
(1.6)\end{array}$ & $\begin{array}{l}0.254 \\
(1.6)\end{array}$ \\
\hline Property rights index & $\begin{array}{l}-0.189 \\
(-2.2)^{* *}\end{array}$ & $\begin{array}{l}-0.165 \\
(-1.8)^{*}\end{array}$ & $\begin{array}{l}-0.112 \\
(-2.0)^{*}\end{array}$ & $\begin{array}{l}-0.099 \\
(-1.8)^{*}\end{array}$ \\
\hline Creditor rights index & $\begin{array}{l}0.156 \\
(1.2)\end{array}$ & $\begin{array}{c}0.16 \\
(1.1)\end{array}$ & $\begin{array}{l}-0.026 \\
(-0.3)\end{array}$ & $\begin{array}{l}0.005 \\
(0.0)\end{array}$ \\
\hline English language dummy & & $\begin{array}{l}-0.113 \\
(-0.5)\end{array}$ & & $\begin{array}{l}0.274 \\
(3.0)^{* * *}\end{array}$ \\
\hline Protestant dummy & & $\begin{array}{l}-0.298 \\
(-0.8)\end{array}$ & & $\begin{array}{l}-0.432 \\
(-1.8)^{*}\end{array}$ \\
\hline Constant & $\begin{array}{l}3.838 \\
(1.2)\end{array}$ & $\begin{array}{l}3.281 \\
(0.9)\end{array}$ & $\begin{array}{l}-0.896 \\
(-0.3)\end{array}$ & $\begin{array}{l}-1.635 \\
(-0.5)\end{array}$ \\
\hline Observations & 28 & 28 & 28 & 28 \\
\hline R-squared & 0.37 & 0.39 & 0.41 & 0.49 \\
\hline
\end{tabular}


Table 10

Loan spreads on ownership-control disparity, property rights protection, and firm characteristics

The sample consists of 319 loans to borrowers in Asian and European countries. Loans are included if the borrowers have financial data on WorldScope and ownership-control disparity data on Lang et al. database. Regression specifications in (1), (3), and (5) include country dummies and all regressions include year fixed effects. The dependent variable is the natural log of loan spreads. Independent variables include borrower ownership-control disparity, property rights index of the country of the borrower, firm's log of total assets, profitability (net income plus depreciation divided by total assets), leverage (total debt divided by market capitalization), capital expenditure to total assets ratio, market-to-book assets ratio, intangible assets ratio (intangible assets divided by total assets). Numbers in parentheses are t-statistics corrected for heteroscedasticity. ${ }^{* * *}$ Significant at the 1 percent level. ${ }^{* *}$ Significant at the 5 percent level. *Significant at the 10 percent level.

\begin{tabular}{|c|c|c|c|c|c|c|}
\hline & \multicolumn{2}{|c|}{$\begin{array}{c}\text { Both Asian and } \\
\text { European countries }\end{array}$} & \multicolumn{2}{|c|}{ Asian countries only } & \multicolumn{2}{|c|}{$\begin{array}{c}\text { European countries } \\
\text { only }\end{array}$} \\
\hline $\begin{array}{l}\text { Ownership-control } \\
\text { disparity }\end{array}$ & $\begin{array}{c}(1) \\
0.007 \\
(1.9)^{*}\end{array}$ & $\begin{array}{c}(2) \\
0.009 \\
(2.3)^{* *}\end{array}$ & $\begin{array}{c}(3) \\
0.015 \\
(2.7)^{* * *}\end{array}$ & $\begin{array}{c}(4) \\
0.020 \\
(3.7)^{* * *}\end{array}$ & $\begin{array}{c}(5) \\
0.004 \\
(0.8)\end{array}$ & $\begin{array}{c}(6) \\
0.010 \\
(2.1)^{* *}\end{array}$ \\
\hline Property rights index & & $\begin{array}{r}-0.184 \\
(-12.5)^{* * *}\end{array}$ & & $\begin{array}{l}-0.076 \\
(-4.8)^{* * *}\end{array}$ & & $\begin{array}{l}-0.274 \\
(-5.2)^{* * *}\end{array}$ \\
\hline Log of assets & $\begin{array}{c}-0.239 \\
(-9.8)^{* * *}\end{array}$ & $\begin{array}{r}-0.169 \\
(-10.8)^{* * *}\end{array}$ & $\begin{array}{c}-0.129 \\
(-4.6)^{* * *}\end{array}$ & $\begin{array}{l}-0.118 \\
(-6.5)^{* * *}\end{array}$ & $\begin{array}{c}-0.304 \\
(-9.0)^{* * *}\end{array}$ & $\begin{array}{l}-0.214 \\
(-9.5)^{* * *}\end{array}$ \\
\hline Profitability & $\begin{array}{l}-1.283 \\
(-2.2)^{* *}\end{array}$ & $\begin{array}{l}-1.663 \\
(-2.8)^{* * *}\end{array}$ & $\begin{array}{l}0.115 \\
(0.2)\end{array}$ & $\begin{array}{l}0.082 \\
(0.1)\end{array}$ & $\begin{array}{l}-1.794 \\
(-2.4)^{* *}\end{array}$ & $\begin{array}{l}-1.699 \\
(-2.2)^{* *}\end{array}$ \\
\hline $\begin{array}{l}\text { Debt to market } \\
\text { capitalization }\end{array}$ & $\begin{array}{l}0.951 \\
(4.6)^{* * *}\end{array}$ & $\begin{array}{l}0.959 \\
(4.6)^{* * *}\end{array}$ & $\begin{array}{l}0.429 \\
(1.6)\end{array}$ & $\begin{array}{r}0.27 \\
(1.1)\end{array}$ & $\begin{array}{l}1.328 \\
(4.6)^{* * *}\end{array}$ & $\begin{array}{l}1.449 \\
(4.9)^{* * *}\end{array}$ \\
\hline $\begin{array}{l}\text { Capital expenditures } \\
\text { to assets }\end{array}$ & $\begin{array}{l}0.644 \\
(1.4)\end{array}$ & $\begin{array}{l}0.043 \\
(0.1)\end{array}$ & $\begin{array}{l}1.382 \\
(1.9)^{*}\end{array}$ & $\begin{array}{l}1.096 \\
(1.4)\end{array}$ & $\begin{array}{l}0.304 \\
(0.5)\end{array}$ & $\begin{array}{l}0.268 \\
(0.5)\end{array}$ \\
\hline $\begin{array}{l}\text { Market to book } \\
\text { assets ratio }\end{array}$ & $\begin{array}{l}0.041 \\
(1.1)\end{array}$ & $\begin{array}{l}0.035 \\
(0.9)\end{array}$ & $\begin{array}{l}-0.152 \\
(-1.7)^{*}\end{array}$ & $\begin{array}{l}-0.233 \\
(-2.5)^{* *}\end{array}$ & $\begin{array}{l}0.082 \\
(1.9)^{*}\end{array}$ & $\begin{array}{l}0.071 \\
(1.6)\end{array}$ \\
\hline $\begin{array}{l}\text { Intangible to assets } \\
\text { ratio }\end{array}$ & $\begin{array}{l}-0.043 \\
(-0.1)\end{array}$ & $\begin{array}{l}-0.475 \\
(-1.3)\end{array}$ & $\begin{array}{l}0.022 \\
(0.0)\end{array}$ & $\begin{array}{l}-0.507 \\
(-1.1)\end{array}$ & $\begin{array}{l}-0.088 \\
(-0.2)\end{array}$ & $\begin{array}{l}0.404 \\
(0.9)\end{array}$ \\
\hline Constant & $\begin{array}{c}6.421 \\
(10.2)^{* * *}\end{array}$ & $\begin{array}{r}10.396 \\
(19.9)^{* * *}\end{array}$ & $\begin{array}{c}6.175 \\
(10.2)^{* * *}\end{array}$ & $\begin{array}{c}7.74 \\
(13.7)^{* * *}\end{array}$ & $\begin{array}{r}7.386 \\
(12.7)^{* * *}\end{array}$ & $\begin{array}{l}12.996 \\
(8.0)^{* * *}\end{array}$ \\
\hline $\begin{array}{l}\text { Country dummies } \\
\text { Year dummies }\end{array}$ & $\begin{array}{l}\text { Yes } \\
\text { Yes }\end{array}$ & $\begin{array}{l}\text { No } \\
\text { Yes }\end{array}$ & $\begin{array}{l}\text { Yes } \\
\text { Yes }\end{array}$ & $\begin{array}{l}\text { No } \\
\text { Yes }\end{array}$ & $\begin{array}{l}\text { Yes } \\
\text { Yes }\end{array}$ & $\begin{array}{l}\text { No } \\
\text { Yes }\end{array}$ \\
\hline $\begin{array}{l}\text { Observations } \\
\text { R-squared }\end{array}$ & $\begin{array}{l}319 \\
0.59\end{array}$ & $\begin{array}{l}319 \\
0.45\end{array}$ & $\begin{array}{l}100 \\
0.62\end{array}$ & $\begin{array}{l}100 \\
0.56\end{array}$ & $\begin{array}{c}219 \\
0.50\end{array}$ & $\begin{array}{r}219 \\
0.42\end{array}$ \\
\hline
\end{tabular}


Appendix 1

Descriptive statistics for loan borrowers and Worldscope firms

This table presents descriptive statistics on borrowers with data on the WorldScope database and Worldscope firms. The statistics reported are for 28 countries where both loan and financial statement data are available. Profitability is defined as the ratio of net income plus depreciation divided by total assets. Debt to market capitalization is defined as the ratio of total debt divided by debt plus market value of equity. Market to book assets ratio is defined as market value of assets divided by book value of assets. Capital expenditure to assets ratio is capital expenditures divided by total assets. Intangible to total assets ratio is defined as the ratio of intangibles to total assets.

Panel A: Summary statistics for loan borrowers

\begin{tabular}{|c|c|c|c|c|c|}
\hline & $\mathrm{N}$ & Mean & $\begin{array}{c}25 \text { th } \\
\text { percentile }\end{array}$ & Median & $\begin{array}{c}75^{\text {th }} \\
\text { percentile }\end{array}$ \\
\hline Total assets (in US\$) & 4,222 & 3415.61 & 160.52 & 576.90 & 2005.13 \\
\hline Profitability & 4,222 & 0.12 & 0.08 & 0.12 & 0.17 \\
\hline Operating income growth rate & 3,324 & 0.65 & -0.01 & 0.21 & 0.52 \\
\hline Debt to market capitalization & 4,222 & 0.30 & 0.12 & 0.26 & 0.44 \\
\hline Market to book assets ratio & 4,222 & 1.56 & 0.85 & 1.17 & 1.75 \\
\hline Capital expenditure to assets ratio & 4,222 & 0.07 & 0.03 & 0.05 & 0.09 \\
\hline Intangible to total assets ratio & 4,222 & 0.17 & 0.02 & 0.10 & 0.25 \\
\hline \multicolumn{6}{|c|}{ Panel B: Summary statistics for Worldscope firms } \\
\hline & $\mathrm{N}$ & Mean & $\begin{array}{c}25 \text { th } \\
\text { percentile }\end{array}$ & Median & $\begin{array}{c}75 \text { th } \\
\text { percentile }\end{array}$ \\
\hline Total assets (in US\$) & 58,442 & 1715.79 & 50.03 & 189.88 & 768.45 \\
\hline Profitability & 58,442 & -0.20 & 0.03 & 0.10 & 0.15 \\
\hline Operating income growth rate & 39,879 & 1.99 & -0.11 & 0.13 & 0.43 \\
\hline Debt to market capitalization & 58,442 & 0.28 & 0.05 & 0.22 & 0.45 \\
\hline Market to book assets ratio & 58,442 & 4.06 & 0.38 & 0.73 & 1.43 \\
\hline Capital expenditure to assets ratio & 58,442 & 0.07 & 0.02 & 0.04 & 0.08 \\
\hline Intangible to total assets ratio & 58,442 & 0.08 & 0.00 & 0.01 & 0.09 \\
\hline
\end{tabular}

